\title{
Influence of Irrigation Regimes at Different Growth Stages on Development and Yield in Maize ( $\mathrm{Zea}$ mays L.)
}

\author{
H.S. Gharib ${ }^{\#}$, A.S. EL-Henawy ${ }^{*}$ and M.E. Meleha ${ }^{* *}$ \\ Agronomy Dept.; *Soil and Water Dept., Fac. Agric., \\ Kafrelshiekh University, Kafr El-Shiekh and **Water \\ Management Research Institute, National Water Research Center, \\ Cairo, Egypt.
}

\begin{abstract}
T HE MAIZE (Zea mays L.) was grown on a clay soil at Irrigation Development Area of Alwezaria, Kafr El-Shiekh, Egypt, during 2012 and 2013 seasons, to study the effect of irrigation regimes during different growth stages on growth, grain yield and water relations. Irrigation was applied at 50\% (high level, H) and 65\% (low level, L) depletion of available soil moisture (DAM) during different growth stages [vegetative stage $\left(\mathrm{S}_{1}\right)$ from the third leaf $(\mathrm{V} 3)$ to onset tasseling (VT) stages, reproductive stage I $\left(\mathrm{S}_{2}\right)$ from VT to mid-milk (R3) stages, reproductive stage II $\left(\mathrm{S}_{3}\right)$ from mid R3 to physiological maturity (R6)].
\end{abstract}

$\mathrm{I}_{\mathrm{HHH}}$ treatment (Irrigated at 50\% DAM during three growth stages) or $\mathrm{I}_{\mathrm{HHL}}$ (Irrigated with 65\% DAM at $\mathrm{S}_{3}$ stage only and 50\% DAM was used during $S_{1}$ and $S_{2}$ growth stages), $I_{\text {LHH }}$ (Irrigated with 65\% DAM at $S_{1}$ growth stage only and 50\% DAM was observed during $S_{2}$ and $S_{3}$ growth stages) and $\mathrm{I}_{\mathrm{LHL}}$ (Irrigated with $50 \% \mathrm{DAM}$ at $\mathrm{S}_{2}$ growth stage only and $65 \%$ DAM was observed during $\mathrm{S}_{1}$ and $\mathrm{S}_{3}$ growth stages) resulted in significant increase in leaf area index (LAI) and dry weight/plant at 99 days after sowing (DAS), crop growth rate (CGR) at the period of 81-99 DAS, ear length, ear diameter, kernels number/ear, grain weight/ear, 100grain weight and grain yield compared with $\mathrm{I}_{\mathrm{LLL}}$ (Irrigated with 65\% DAM during three growth stages ) in the two seasons. There were no significant differences in grain yield among the irrigation treatments $\mathrm{I}_{\mathrm{HHH}}, \mathrm{I}_{\mathrm{HHL}}, \mathrm{I}_{\mathrm{LHH}}$ and $\mathrm{I}_{\mathrm{LHL}}$ in the mentioned traits in both seasons.

Abundance soil moisture in root zone during $\mathrm{S}_{2}$ stage (containing tasseling, silking, blister and mid-milk stages) is necessary to achieve high grain yield equal to that during entire season. $\mathrm{I}_{\mathrm{HHH}}$ treatment recorded the highest values of applied water $\left(7286\right.$ and $7321 \mathrm{~m}^{3} / \mathrm{ha}$ ), while $\mathrm{I}_{\mathrm{LLL}}$ recorded the lowest values 6171 and $6198 \mathrm{~m}^{3} / \mathrm{ha}$ in the two seasons. Although, the treatments received irrigation at $50 \%$ DAM during $\mathrm{S}_{2}$ stage $\left(\mathrm{I}_{\mathrm{HHL}}, \mathrm{I}_{\mathrm{LHH}}\right.$ and $\mathrm{I}_{\mathrm{LHL}}$ treatments) were equivalent to those received irrigation at 50\% DAM during entire seasons $\left(\mathrm{I}_{\mathrm{HHH}}\right.$ treatment), they were lower in amount of applied irrigation water and water consumptive use. They saved at least $11.3,16.0$ and $19.9 \%$ applied water parallel with the yield decrease at the most $3.1,3.2$ and $5.3 \%$ than $\mathrm{I}_{\mathrm{HHH}}$ treatment, respectively. Also, they increased the productivity of applied water $\left(\mathrm{WP}_{\text {water applied }}\right)$ and water consumptive use (WP wCU $)\left(\mathrm{kg}\right.$ grain $/ \mathrm{m}^{3}$ water) compared with $\mathrm{I}_{\mathrm{HHH}}$ in both seasons.

\#Corresponding author email address: hanysony@yahoo.com 
At North Delta, Penman Monteith equation can be used in determining the actual consumptive use and the average of crop Coefficient $(\mathrm{Kc})$ for the two seasons was found to be $0.43,0.54,0.64,0.58$ and 0.51 during emergence, vegetative, tasseling to milk, milk to dent and dent to maturity stages, respectively. Therefore, when irrigation water becomes a limited factor for agriculture, we can apply $\mathrm{I}_{\mathrm{LHL}}$ treatment which resulted in high grain yield and water productivity equal to $\mathrm{I}_{\mathrm{HHH}}$ with less amount of applied irrigation water and consumptive use in Kafr El-Shiekh Governorate.

Keywords: Evapotranspiration, Growth stages, Water consumptive use, Water depletion, Water stress, Maize, (Zea mays L.).

Maize (Zea mays, L.) is one of the most important summer crops in Egypt. Cultivated area was about750000 ha of land with 5.8 megatons produced in 2014(FAO, 2014). Agriculture consumes more than $85 \%$ of Egypt's share of Nile water annually(MWRIE, 2014).Although Egypt suffer from relative scarcity of water resources, we need more water to reclaim new lands to meet the increase in demand for food (Hafez \& Gharib, 2016). Improvement and development water management is expected to increase water efficiency and saving some water for new reclaim territory. Knowledge of consumptive use is necessary for planning farm irrigation systems and improving irrigation practices. Managers of these crops can determine how much supplemental water is needed to achieve maximum productivity with less water (Kebede et al., 2014).

Evapotranspiration (water consumptive use) is a Standard method for the estimation of water requirement which should be applied under field condition (Kullberg, 2015). Many experiments conducted to deficit irrigation scheduling during different growth stages (Ge et al., 2012 and Igbadun et al., 2008). Mansouri-Far et al. (2010) reveals that identifying the most sensitive stage of the plant development to water deficit is a way to enhance crop production.

Igbadun et al. (2008) showed that water deficit treatment which irrigation was skipped every other week at all growth stages of maize induced reduction in leaf area index, dry matter and grain yields and seasonal evapotranspiration. While the highest water use efficiency was under full irrigation, maximum irrigation water use efficiency was obtained in the deficit irrigation treatment at vegetative growth stage. Mansouri-Far et al. (2010) reported that the reproductive stage was more sensitive to water stress than the vegetative stage in yield reduction. The 100-kernel weight was the most sensitive yield component when the water deficit treatments occurred in low-sensitive growth stages. Leaf area index was reduced about $15 \%$ under water deficit at vegetative stage. Ge et al. (2012) pointed out that grain yield and ear kernel number decreased, respectively, by range from 20.4 to $26.1 \%$ and 12.1 to $19.7 \%$ for $55 \%$ field capacity (FC), and 59.2 to $84.5 \%$ and 39.8 to $88.1 \%$ for $35 \%$ FC. However, $55 \%$ FC reduced plant height, leaf area, biomass accumulation, net photosynthesis and ear length and diameter compare to $75 \%$ FC. Water use efficiency (WUE) 
decreased at thirteenth leaf (V13) and harvest stage (R3), while WUE increased at sixteenth leaf (V16) and silking stage (R1) under 55\% FC.

Farré \& Faci (2009) indicated that flowering was the most sensitive stage of maize to water deficit. Grain yield was obtained under deficit irrigation around flowering treatment $691 \mathrm{~g} \mathrm{~m}^{-2}$, while well-irrigated treatments was $1069 \mathrm{~g} \mathrm{~m}^{-2}$. (Çakir, 2004) found that deficit irrigation during vegetative and tasseling stage reduced plant height and leaf area index as a result of reducing size of the leaves. Short-duration water stress at the rapid vegetative growth reduced final dry matter weight $28-32 \%$. A single irrigation skip during one of the sensitive growth stages or both the tasseling and ear formation stages may cause a 30-40\% and 66-93\% grain yield loss respectively. Bahadori et al. (2015) stated that during flowering stage, one single day of water stress can potentially decrease yield up to $8 \%$. Ghooshchi et al. (2008) indicated that yield reduction due to water stress before silking, silking and filling growth stages was $12.5,42.0$ and $22.5 \%$ respectively. Kuşçu \& Demir (2012) observed that the full irrigation treatment (VFG) gave the highest seasonal evapotranspiration. There are insignificant differences between the VFG and $25 \%$ water deficit at grain-filling stage (VFG75) treatments ingrain yield and dry matter yield. The flowering and vegetative stages were recorded as the most sensitive stages to water deficit. Djaman (2011) concluded that Irrigation regime of $25 \%$ water saving could ensure satisfactory grain yield of maize and increment of WUE. Crop evapotranspiration increased with irrigation amounts while it decreased with irrigation regimes. Grain yield losses due to the water stress is varied between 1 to $76 \%$ depending on the severity, timing and stage of occurrence (Mostafavi et al., 2011 and Zarabi et al., 2011).

The objectives of this work were to study the effect of irrigation water regime based on depletion of available soil moisture at different growth stages on growth, grain yield, yield attributes, water consumptive use and amount of applied water and water productivity of maize cv. SC10.

\section{Materials and Methods}

Two field experiments were conducted in summer 2012 and 2013at the field of Irrigation Development Area of Alwezaria $\left(31^{\circ} 11^{\prime} \mathrm{N}, 30^{\circ} 57^{\prime} \mathrm{E}\right)$, Kafr El-Shiekh Governorate , in Northern Egypt. The experimental soil was clay in texture with a $\mathrm{pH}$ of 7.8. Organic matter, total nitrogen, available phosphorus and available potassium were $1.49 \%, 0.14 \%$ ,15.8 $\mathrm{mg} \mathrm{kg}^{-1}$ and $250 \mathrm{mg} \mathrm{kg}^{-1}$, respectively (Black et al., 1965). Depth of water table for experimental soil was $70-90 \mathrm{~cm}$. The soil physical analysis were determined in the experimental sites as given in Table 1.Weather data from planting to harvest were collected from Sakha Meteorological Stations (Table 2).

SC10 single cross maize (Zea mays L.) was planted on $25^{\text {th }}$ and $15^{\text {th }}$ May in 2012 and 2013 seasons, respectively. The preceding crop was Egyptian clover in both seasons. Seeds of the maize cultivar "SC10" were sown on one side of ridge in hills $25 \mathrm{~cm}$ apart at the rate of 2-3 seed per hill. One plant per hill was maintained by thinning at 18 days after sowing. The plant population density was 57143 plants ha $^{-1}$ for two seasons. Phosphorus at $360 \mathrm{~kg}$ of 
Calcium superphosphate $\left(15.5 \% \mathrm{P}_{2} \mathrm{O}_{5}\right)$ and potassium at $100 \mathrm{~kg}$ of potassium sulphate (48 $\% \mathrm{~K}_{2} \mathrm{O}$ ) were applied per hectare during soil preparation. Maize plants were fertilized with $286 \mathrm{~kg} \mathrm{~N} / \mathrm{ha}$ in form of urea $(46 \% \mathrm{~N})$ in two equal splits, before the first irrigation after 21 days from sowing and before the second irrigation. Other cultural practices were done as recommended.

TABLE1. Soil physical of the experimental site in 2012 and 2013 seasons.

\begin{tabular}{|l|c|c|c|c|c|c|}
\hline \multirow{2}{*}{$\begin{array}{l}\text { Soil depth } \\
\text { (cm) }\end{array}$} & \multicolumn{2}{|c|}{ Field capacity \% } & \multicolumn{2}{c|}{ Wilting point \% } & \multicolumn{2}{c|}{ Bulk density $\left(\mathbf{g} / \mathbf{c m}^{\mathbf{3}}\right)$} \\
\cline { 2 - 7 } & $\mathbf{2 0 1 2}$ & $\mathbf{2 0 1 3}$ & $\mathbf{2 0 1 2}$ & $\mathbf{2 0 1 3}$ & $\mathbf{2 0 1 2}$ & $\mathbf{2 0 1 3}$ \\
\hline $0-20$ & 44.17 & 44.74 & 24.03 & 24.34 & 1.03 & 1.02 \\
$20-40$ & 39.12 & 38.94 & 21.27 & 21.17 & 1.16 & 1.16 \\
$40-60$ & 36.79 & 36.65 & 19.82 & 19.75 & 1.23 & 1.24 \\
Mean & 40.03 & 40.11 & 21.71 & 21.75 & 1.14 & 1.14 \\
\hline
\end{tabular}

TABLE2. Mean monthly of weather data during 2012 and 2013 seasons.

\begin{tabular}{|l|c|c|c|c|c|c|}
\hline \multirow{2}{*}{ Month } & \multicolumn{2}{|c|}{ Temperature $\left(\mathbf{C}^{\mathbf{0}}\right)$} & \multicolumn{2}{|c|}{ Relative humidity (\%) } & \multicolumn{2}{c|}{ Wind speed (km/day) } \\
\cline { 2 - 7 } & $\mathbf{2 0 1 2}$ & $\mathbf{2 0 1 3}$ & $\mathbf{2 0 1 2}$ & $\mathbf{2 0 1 3}$ & $\mathbf{2 0 1 2}$ & $\mathbf{2 0 1 3}$ \\
\hline May & 25.80 & 26.62 & 62.88 & 60.40 & 100.1 & 102.7 \\
June & 28.46 & 28.21 & 65.19 & 62.95 & 104.0 & 115.4 \\
July & 29.23 & 28.32 & 68.54 & 67.14 & 91.7 & 111.0 \\
August & 29.84 & 29.28 & 68.52 & 76.58 & 90.9 & 90.2 \\
September & 27.51 & 27.74 & 67.58 & 68.80 & 111.0 & 87.6 \\
\hline
\end{tabular}

The treatments were irrigation at 50\% (high level, $\mathrm{H}$ ) or $65 \%$ (low level, L) depletion of the available soil moisture (DAM) during three growth stages as shown in Table 3. Vegetative corn growth stages was determined according Ritchie et al. (1993).

TABLE 3. Irrigation regime during different growth stages of maize.

\begin{tabular}{|c|c|c|c|c|c|}
\hline \multirow{2}{*}{\multicolumn{2}{|c|}{ Treatments }} & \multicolumn{3}{|c|}{ Growth stages } & \multirow{3}{*}{\begin{tabular}{|l|} 
Description \\
$\begin{array}{l}\text { Irrigated with 50\% depletion of available soil moisture (DAM) } \\
\text { during three growth stages }\end{array}$
\end{tabular}} \\
\hline & & \multirow{2}{*}{\begin{tabular}{|l|}
$S_{1}$ \\
$H$
\end{tabular}} & \multirow{2}{*}{$\frac{\mathbf{S}_{\mathbf{2}}}{\mathrm{H}}$} & \multirow{2}{*}{$\frac{S_{3}}{H}$} & \\
\hline 1. & $\mathrm{I}_{\mathrm{HHH}}$ & & & & \\
\hline 2. & $\mathrm{I}_{\mathrm{HHL}}$ & $\mathrm{H}$ & $\mathrm{H}$ & $\mathrm{L}$ & $\begin{array}{l}\text { Irrigated with } 65 \% \text { (DAM) at } \mathrm{S}_{3} \text { growth stage only. } 50 \% \\
(\mathrm{DAM}) \text { was observed during } \mathrm{S}_{1} \text { and } \mathrm{S}_{2} \text { growth stages }\end{array}$ \\
\hline 3. & $\mathrm{I}_{\mathrm{HLH}}$ & $\mathrm{H}$ & $\mathrm{L}$ & $\mathrm{H}$ & $\begin{array}{l}\text { Irrigated with } 65 \% \text { (DAM) at } \mathrm{S}_{2} \text { growth stage only. } 50 \% \\
\text { (DAM) was observed during } \mathrm{S}_{1} \text { and } \mathrm{S}_{3} \text { growth stages } \\
\end{array}$ \\
\hline 4. & $\mathrm{I}_{\mathrm{HLL}}$ & $\mathrm{H}$ & $\mathrm{L}$ & $\mathrm{L}$ & $\begin{array}{l}\text { Irrigated with } 50 \% \text { (DAM) at } \mathrm{S}_{1} \text { growth stage only. 65\% } \\
\text { (DAM) was observed during } \mathrm{S}_{2} \text { and } \mathrm{S}_{3} \text { growth stages } \\
\end{array}$ \\
\hline 5. & $\mathrm{I}_{\mathrm{LHH}}$ & $\mathrm{L}$ & $\mathrm{H}$ & $\mathrm{H}$ & $\begin{array}{l}\text { Irrigated with } 65 \% \text { (DAM) at } \mathrm{S}_{1} \text { growth stage only. } 50 \% \\
\text { (DAM) was observed during } \mathrm{S}_{2} \text { and } \mathrm{S}_{3} \text { growth stages } \\
\end{array}$ \\
\hline 6. & $\mathrm{I}_{\mathrm{LHL}}$ & $\mathrm{L}$ & $\mathrm{H}$ & $\mathrm{L}$ & $\begin{array}{l}\text { Irrigated with } 50 \% \text { (DAM) at } \mathrm{S}_{2} \text { growth stage only. 65\% } \\
\text { (DAM) was observed during } \mathrm{S}_{1} \text { and } \mathrm{S}_{3} \text { growth stages }\end{array}$ \\
\hline 7. & $\mathrm{I}_{\mathrm{LLH}}$ & $\mathrm{L}$ & $\mathrm{L}$ & $\mathrm{H}$ & $\begin{array}{l}\text { Irrigated with } 50 \% \text { (DAM) at } \mathrm{S}_{3} \text { growth stage only. 65\% } \\
(\mathrm{DAM}) \text { was observed during } \mathrm{S}_{1} \text { and } \mathrm{S}_{2} \text { growth stages }\end{array}$ \\
\hline 8 & $\mathrm{I}_{\mathrm{LLL}}$ & $\mathrm{L}$ & $\mathrm{L}$ & $\mathrm{L}$ & Irrigated with $65 \%$ (DAM) during three growth stages \\
\hline
\end{tabular}

Egypt. J. Agron . 38, No.3 (2016) 
A randomized complete block design with four replications was used. Each plot $42 \mathrm{~m}^{2}$ size consisted of 10 ridges $70 \mathrm{~cm}$ apart and $6 \mathrm{~m}$ long to avoid the effect of lateral water leak of irrigation; plots were isolated by levees $1.5 \mathrm{~m}$ wide.

Irrigation treatments started after the first irrigation. In each plot, the two outside ridges were left to avoid border effects and the two following ridges were used for determination growth, while the 6 inner ridges were used for measuring of grain yield and its component. Five guarded plants were randomly taken from each plot at 60,81 and 99 days after sowing (DAS) to estimate dry weight and leaf area per plant. The different plant fractions were washed and oven dried to a constant weight at $70^{\circ} \mathrm{C}$. Portable Area Meter (Model LI3000A) was used to measure leaf area. The growth analysis, viz. leaf area index, crop growth rate and net assimilation rate were computed according to Watson (1952).Ten maize plants from each plot was harvested to determine plant height, ear height, ear length $(\mathrm{cm})$, ear diameter $(\mathrm{cm})$, ear grains weight, shelling $\%$ and 100 -seed weight $(\mathrm{g})$. Maize plants of the 6 inner ridges of each plot were harvested to determine grain yield per hectare (ha).

Amount of applied irrigation water were measured by a portable pump equipped with a water meter for each plot. Actual need for irrigation was determined by drying the soil samples for $24 \mathrm{~h}$ to $105^{\circ} \mathrm{C}$ and the percentage of moisture was expressed on oven dry weight basis. Soil samples were taken at each $20 \mathrm{~cm}$ soil depth to $60 \mathrm{~cm}$ before and after irrigation. Water consumptive use (WCU)was calculated from sowing to harvest using the method of Israelsen \& Hansen (1962):

$\mathrm{WCU}=\frac{\theta_{2}-\theta_{1}}{100} \times \mathrm{B} \cdot \mathrm{d} \times \mathrm{D} \times 4200$

where:

$\mathrm{WCU}=$ Amount of water consumptive use $\left(\mathrm{m}^{3} / \mathrm{ha}\right)$.

$\theta_{2}=$ Soil moisture $\%$ after irrigation .

$\theta_{1}=$ Soil moisture $\%$ before the irrigation.

B.d = Bulk density $\left(\mathrm{g} / \mathrm{cm}^{3}\right)$.

$\mathrm{D}=$ Depth of soil layer $(\mathrm{m})$.

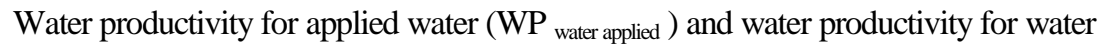
consumptive use (WP water consumptive use ) were measured according to El-Bably et al. (2015)as follows:

$$
\begin{aligned}
& \mathbf{W P} \text { water applied }=\frac{\text { Yield }(\mathrm{kg} / \mathrm{ha})}{\text { Applied water }\left(\mathrm{m}^{3} / \mathbf{h a}\right)} \\
& \mathrm{WP}_{\text {waterconsumptive use }}=\frac{\text { Yield }(\mathrm{kg} / \mathrm{ha})}{\text { water consumpitive use }\left(\mathrm{m}^{3} / \mathrm{ha}\right)}
\end{aligned}
$$

Crop coefficient $(\mathrm{Kc})$ was calculated according to Penman Monteith method as the ratio between actual crop evapotranspiration $\left(\mathrm{ET}_{\mathrm{a}}\right)$ and reference evapotranspiration $\left(\mathrm{ET}_{\mathrm{o}}\right)$ as follows: 


$$
K c=\frac{\mathrm{ETa}}{\mathrm{ETO}}
$$

Reference evapotranspiration $\left(\mathrm{ET}_{\mathrm{o}}\right.$ ) was calculated by FAO Penman Monteith (Allen et al., 1998).

Analysis of variance (ANOVA) was assessed according to Gomez \& Gomez (1984) and the means were compared by Duncan's Multiple Range Test (Duncan, 1955). The data was analyzed using CoStat software for windows (version 6.3).

\section{Growth}

\section{Results and Discussion}

Table 4 shows significant effect of water deficit treatment in the leaf area index (LAI) and dry weight (g/plant) of the maize at 60, 81 and 99 days after sowing (DAS) for the 2012 and 2013 seasons. At 60 DAS, irrigation treatment $I_{H}$ during $S_{1}$ stage resulted in a significant increase in LAI and dry weight/plant compared with $\mathrm{I}_{\mathrm{L}}$ treatment in the two seasons.

TABLE 4. Leaf area index and dry matter accumulation of hybrid maize cv. SC10 at 60, 81 and 99 days after sowing (DAS) as affected by irrigation regime at different growth sages in 2012 and 2013 seasons.

\begin{tabular}{|c|c|c|c|c|c|c|c|}
\hline \multirow{2}{*}{$\begin{array}{l}\text { Irrigation } \\
\text { treatments }\end{array}$} & \multicolumn{3}{|c|}{ Growth stages } & \multicolumn{2}{|c|}{ Leaf area index } & \multicolumn{2}{|c|}{ Dry weight (g/plant) } \\
\hline & $\mathbf{S}_{1}$ & $\mathbf{S}_{2}$ & $\mathbf{S}_{\mathbf{3}}$ & 2012 & 2013 & 2012 & 2013 \\
\hline \multicolumn{8}{|c|}{ At 60 DAS } \\
\hline $\mathrm{I}_{\mathrm{H}}$ & $\mathrm{H}$ & - & - & $4.66 \mathrm{a}$ & $4.59 \mathrm{a}$ & $204.0 \mathrm{a}$ & $221.4 \mathrm{a}$ \\
\hline $\mathrm{I}_{\mathrm{L}}$ & $\mathrm{L}$ & - & - & $4.07 \mathrm{~b}$ & $4.23 \mathrm{~b}$ & $189.4 \mathrm{~b}$ & $200.8 \mathrm{~b}$ \\
\hline \multicolumn{4}{|c|}{ F test } & *** & $*$ & $*$ & $* *$ \\
\hline \multicolumn{8}{|c|}{ At 81 DAS } \\
\hline $\mathrm{I}_{\mathrm{HH}}$ & $\mathrm{H}$ & $\mathrm{H}$ & - & $6.10 \mathrm{a}$ & $6.20 \mathrm{a}$ & $294.3 \mathrm{a}$ & $314.0 \mathrm{a}$ \\
\hline $\mathrm{I}_{\mathrm{HL}}$ & $\mathrm{H}$ & $\mathrm{L}$ & - & $5.45 \mathrm{~b}$ & $5.39 \mathrm{~b}$ & $279.3 \mathrm{~b}$ & $289.0 \mathrm{~b}$ \\
\hline $\mathrm{I}_{\mathrm{LH}}$ & $\mathrm{L}$ & $\mathrm{H}$ & - & $5.98 \mathrm{a}$ & $6.07 \mathrm{a}$ & $281.3 \mathrm{ab}$ & $297.1 \mathrm{ab}$ \\
\hline $\mathrm{I}_{\mathrm{LL}}$ & $\mathrm{L}$ & $\mathrm{L}$ & - & $4.73 \mathrm{c}$ & $4.81 \mathrm{c}$ & $249.2 \mathrm{c}$ & $258.4 \mathrm{c}$ \\
\hline \multicolumn{4}{|c|}{ F test } & $* *$ & $* *$ & *** & $* *$ \\
\hline \multicolumn{8}{|c|}{ At 99 DAS } \\
\hline $\mathrm{I}_{\mathrm{HHH}}$ & $\mathrm{H}$ & $\mathrm{H}$ & $\mathrm{H}$ & $6.01 \mathrm{a}$ & $5.93 \mathrm{a}$ & $397.8 \mathrm{a}$ & $422.4 \mathrm{a}$ \\
\hline $\mathrm{I}_{\mathrm{HHL}}$ & $\mathrm{H}$ & $\mathrm{H}$ & $\mathrm{L}$ & $5.78 \mathrm{a}$ & $5.86 \mathrm{a}$ & $389.0 \mathrm{a}$ & $417.4 \mathrm{a}$ \\
\hline $\mathrm{I}_{\mathrm{HLH}}$ & $\mathrm{H}$ & $\mathrm{L}$ & $\mathrm{H}$ & $5.07 \mathrm{~b}$ & $5.21 \mathrm{~b}$ & $359.0 \mathrm{bc}$ & $369.6 \mathrm{~b}$ \\
\hline $\mathrm{I}_{\mathrm{HLL}}$ & $\mathrm{H}$ & $\mathrm{L}$ & $\mathrm{L}$ & $4.51 \mathrm{c}$ & $4.89 \mathrm{c}$ & $351.0 \mathrm{c}$ & $355.2 \mathrm{~b}$ \\
\hline $\mathrm{I}_{\mathrm{LHH}}$ & $\mathrm{L}$ & $\mathrm{H}$ & $\mathrm{H}$ & $5.61 \mathrm{a}$ & $5.73 \mathrm{a}$ & $381.3 \mathrm{a}$ & $401.8 \mathrm{a}$ \\
\hline $\mathrm{I}_{\mathrm{LHL}}$ & $\mathrm{L}$ & $\mathrm{H}$ & $\mathrm{L}$ & $5.52 \mathrm{ab}$ & $5.79 a$ & $378.6 \mathrm{ab}$ & $395.9 \mathrm{a}$ \\
\hline $\mathrm{I}_{L H}$ & $\mathrm{~L}$ & $\mathrm{~L}$ & $\mathrm{H}$ & $4.17 \mathrm{~cd}$ & $4.06 \mathrm{~d}$ & $341.2 \mathrm{~cd}$ & $351.7 \mathrm{bc}$ \\
\hline $\mathrm{I}_{L L}$ & $\mathrm{~L}$ & $\mathrm{~L}$ & $\mathrm{~L}$ & $3.85 \mathrm{~d}$ & $3.94 \mathrm{~d}$ & $321.8 \mathrm{~d}$ & $328.4 \mathrm{c}$ \\
\hline \multicolumn{4}{|c|}{ F test } & $* *$ & *** & $*$ & $* *$ \\
\hline
\end{tabular}

$\mathbf{S}_{\mathbf{1}}=$ Vegetative stage, started from the third leaf (V3) to onset tasseling (VT) stages; $\mathbf{S}_{2}=$ Reproductive stage I started from VT to mid milk (R3) stages [including VT, silking (R1), blister (R2) and mid R3) stage]; $\mathbf{S}_{3}=$ Reproductive stage II started from mid R3 to physiological maturity (R6) [including dough (R4) and dent (R5) stages].

$\mathbf{H}=$ irrigation at $50 \%$ depletion of the available soil moisture (DAM); $\mathbf{L}=$ irrigation at $65 \%$ DAM.

$*$ and ** indicate $\mathrm{P}<0.05$ and $\mathrm{P}<0.01$ respectively. Means in each column designated by the same letter are not significantly different at 5\% level using Duncan's Multiple Range Test

Egypt. J. Agron . 38, No.3 (2016) 
At 81 DAS, treatments $I_{H H}$ or $I_{L H}$ during the two stages $S_{1}$ and $S_{2}$ produced higher LAI and dry weight/plant than did the other irrigation treatments. At 99 DAS, $\mathrm{I}_{\mathrm{HHH}}, \mathrm{I}_{\mathrm{HHL}}, \mathrm{I}_{\mathrm{LHH}}$ and $\mathrm{I}_{\mathrm{LHL}}$ treatments which plants irrigated at $50 \%$ DAM during the reproductive stage, IVT- R3 markedly exceeded $\mathrm{I}_{\mathrm{HLH}}, \mathrm{I}_{\mathrm{HLL}}, \mathrm{I}_{\mathrm{LLH}}$ and $\mathrm{I}_{\mathrm{LLL}}$ treatments than those irrigated at $65 \%$ DAM at these stages in LAI and dry weight/plant in the two seasons.

Thus, sufficient soil moisture in the root zone through irrigation at $50 \%$ DAM during entire season or from onset tasseling to mid milk stage increased the capacity of maize plants to accumulate dry matter.

However, plants under favorable moisture conditions resulted in good leaf emergence, extension and number (Ge et al., 2012).This may be attributed to the increase in the area of photosynthesizing leaves which in turn resulted in more photosynthates available for dry matter accumulation. These results are in harmony with those of Pandey et al. (2000), who stated that increasing moisture stress resulted in progressively less shoot dry matter. Also, Çakir (2004) and Yllmaz et al. (2010) found that deficit irrigation during vegetative reduced leaf area index as a result of reducing size of the leaves. Short-duration water stress at the rapid vegetative growth reduced final dry matter weight. Total dry matter accumulation was accelerated after each irrigation application. Igbadun et al. (2008) reported that omitted irrigation every other week during the crop growing season gave the least values leaf area index and dry matter of in the two seasons, while weekly irrigation recorded the highest values.

The effects of water regime at different growth stages on crop growth rate (CGR) and net assimilation rate (NAR) were determined for maize (Table 5). Results showed that there is a significant effect in the two seasons.

At the first period 60-81 DAS, the highest CGR and NAR of maize obtained from $\left(\mathrm{I}_{\mathrm{HH}}\right)$ and $\left(\mathrm{I}_{\mathrm{LH}}\right)$ treatments compare to $\left(\mathrm{I}_{\mathrm{HL}}\right)$ and $\left(\mathrm{I}_{\mathrm{LL}}\right)$ at the $\mathrm{S}_{1}$ and $\mathrm{S}_{2}$ stages in 2003 and 2004 seasons. At the period of 81-99 DASI $\mathrm{HHH}_{\mathrm{HH}}, \mathrm{I}_{\mathrm{HHL}}, \mathrm{I}_{\mathrm{LHH}}$ and $\mathrm{I}_{\mathrm{LHL}}$ treatments, being insignificant, resulted in a substantial increase in CGR compared with $\mathrm{I}_{\mathrm{HLH}}, \mathrm{I}_{\mathrm{HLL}}, \mathrm{I}_{\mathrm{LLH}}$ and $\mathrm{I}_{\mathrm{LLL}}$ treatments in both seasons. This may be attributed to the effect of the mentioned treatment on increasing photosynthetic area, which was reflected in higher dry matter accumulation per unit ground area (crop growth rate). Similar results were reported by Abayomi et al.(2012) and Udomprasert et al.(2005).

On contrary, data in Table 5 at the period of 81-90 DAS show that the irrigation treatment $\mathrm{I}_{\mathrm{LLH}}$ produced higher NAR than all the other treatments. Such reduction in NAR obtained from irrigation at 50\% DAM during entire season or during the reproductive stageIVT-R3 may be attributed to very large leaf area which led to increase mutual-shading and transpiration and in turn caused a reduction in rate of assimilation per unit of leaf area (NAR). However, the reduction in NAR at low soil moisture level during entire season $\left(\mathrm{I}_{\mathrm{LLL}}\right)$ may be attributed to decrease LAI which might have decreased light interception and in 
turn decreased dry matter accumulation. These results are accordance with those reported by Abayomi et al. (2012) and Udomprasert et al. (2005), who reported that net assimilation rate was reduced by water stress.

TABLE 5. Crop growth rate (CGR) and net assimilation rate (NAR) of hybrid maize cv. SC10 as affected by irrigation regime at different growth sages in 2012 and 2013 seasons.

\begin{tabular}{|c|c|c|c|c|c|c|c|}
\hline \multirow{2}{*}{$\begin{array}{l}\text { Irrigation } \\
\text { treatments }\end{array}$} & \multicolumn{3}{|c|}{ Growth stages } & \multicolumn{2}{|c|}{ CGR (g/m²/week) } & \multicolumn{2}{|c|}{ NAR $\left(\mathrm{g} / \mathrm{m}^{2} /\right.$ week $)$} \\
\hline & $\mathbf{S}_{1}$ & $\mathbf{S}_{2}$ & $\mathbf{S}_{3}$ & 2012 & 2013 & 2012 & 2013 \\
\hline \multicolumn{8}{|c|}{ At the period of 60-81 DAS } \\
\hline $\mathrm{I}_{\mathrm{HH}}$ & $\mathrm{H}$ & $\mathrm{H}$ & - & $172.0 \mathrm{a}$ & $176.2 \mathrm{a}$ & $32.25 \mathrm{ab}$ & $33.02 \mathrm{a}$ \\
\hline $\mathrm{I}_{\mathrm{HL}}$ & $\mathrm{H}$ & $\mathrm{L}$ & - & $143.5 \mathrm{~b}$ & $128.7 \mathrm{~b}$ & $28.61 \mathrm{bc}$ & $26.06 \mathrm{~b}$ \\
\hline $\mathrm{I}_{\mathrm{LH}}$ & $\mathrm{L}$ & $\mathrm{H}$ & - & $175.0 \mathrm{a}$ & $183.4 \mathrm{a}$ & $35.14 \mathrm{a}$ & $35.85 \mathrm{a}$ \\
\hline $\mathrm{I}_{\mathrm{LL}}$ & $\mathrm{L}$ & $\mathrm{L}$ & - & $113.8 \mathrm{c}$ & $109.7 \mathrm{c}$ & $25.88 \mathrm{c}$ & $24.41 \mathrm{~b}$ \\
\hline F test & & & & $* *$ & $* *$ & $*$ & $* *$ \\
\hline \multicolumn{8}{|c|}{ At the period of 81-99 DAS } \\
\hline $\mathrm{I}_{\mathrm{HHH}}$ & $\mathrm{H}$ & $\mathrm{H}$ & $\mathrm{H}$ & $230.0 \mathrm{a}$ & $241.0 \mathrm{a}$ & $38.13 \mathrm{~b}$ & $40.05 \mathrm{~b}$ \\
\hline $\mathrm{I}_{\mathrm{HHL}}$ & $\mathrm{H}$ & $\mathrm{H}$ & $\mathrm{L}$ & $210.5 \mathrm{ab}$ & $230.0 \mathrm{ab}$ & $35.19 \mathrm{bcd}$ & $38.09 \mathrm{~b}$ \\
\hline \begin{tabular}{|l|}
$\mathrm{ILH}$ \\
\end{tabular} & $\mathrm{H}$ & $\mathrm{L}$ & $\mathrm{H}$ & $177.1 \mathrm{c}$ & $179.1 \mathrm{c}$ & $33.21 \mathrm{~cd}$ & $33.53 \mathrm{c}$ \\
\hline $\mathrm{I}_{\mathrm{HLL}}$ & $\mathrm{H}$ & $\mathrm{L}$ & $\mathrm{L}$ & $159.2 \mathrm{c}$ & $157.1 \mathrm{~cd}$ & $31.75 \mathrm{~d}$ & $28.36 \mathrm{~d}$ \\
\hline $\mathrm{I}_{\mathrm{LHH}}$ & $\mathrm{L}$ & $\mathrm{H}$ & $\mathrm{H}$ & $222.3 \mathrm{ab}$ & $232.7 \mathrm{a}$ & $38.46 \mathrm{~b}$ & $39.78 \mathrm{~b}$ \\
\hline $\mathrm{I}_{\mathrm{LHL}}$ & $\mathrm{L}$ & $\mathrm{H}$ & $\mathrm{L}$ & $216.1 \mathrm{ab}$ & $219.5 \mathrm{ab}$ & $37.29 \mathrm{bc}$ & $37.14 \mathrm{bc}$ \\
\hline $\mathrm{I}_{\text {LLH }}$ & $\mathrm{L}$ & $\mathrm{L}$ & $\mathrm{H}$ & $204.6 \mathrm{~b}$ & $207.2 \mathrm{~b}$ & $46.06 \mathrm{a}$ & $46.84 \mathrm{a}$ \\
\hline $\mathrm{I}_{\text {LLL }}$ & $\mathrm{L}$ & $\mathrm{L}$ & $\mathrm{L}$ & $161.4 \mathrm{c}$ & $155.5 \mathrm{~d}$ & $37.72 \mathrm{~b}$ & $35.6 \mathrm{bc}$ \\
\hline \multicolumn{4}{|l|}{$\mathrm{F}$ test } & $* *$ & $* *$ & $* *$ & $* *$ \\
\hline
\end{tabular}

$\mathbf{S}_{\mathbf{1}}=$ Vegetative stage, started from the third leaf (V3) to onset tasseling (VT) stages; $\mathbf{S}_{2}=$ Reproductive stage I started from VT to mid milk (R3) stages [including VT, silking (R1), blister (R2) and mid R3) stage]; $\mathbf{S}_{\mathbf{3}}=$ Reproductive stage II started from mid R3 to physiological maturity (R6) [including dough (R4) and dent (R5) stages].

$\mathbf{H}=$ irrigation at $50 \%$ depletion of the available soil moisture (DAM); $\mathbf{L}=$ irrigation at $65 \%$ DAM.

$*$ and $* *$ indicate $\mathrm{P}<0.05$ and $\mathrm{P}<0.01$ respectively. Means in each column designated by the same latter are not significantly different at 5\% level using Duncan's Multiple Range Test.

Plant and ear height were significantly affected by irrigation regime during different growth stages in the two seasons (Table 6). $\mathrm{I}_{\mathrm{HHH}}, \mathrm{I}_{\mathrm{HHL}}, \mathrm{I}_{\mathrm{HLH}}$ and $\mathrm{I}_{\mathrm{HLL}}$ treatments which plants irrigated at $50 \%$ DAM during vegetative growth stage, being insignificant, were taller than $\mathrm{I}_{\mathrm{LHH}}, \mathrm{I}_{\mathrm{LHL}}, \mathrm{I}_{\mathrm{LLH}}$ and $\mathrm{I}_{\mathrm{LLL}}$ treatments which Irrigated at $65 \%$ DAM during vegetative stage in both seasons. Generally, water stress through irrigation based on low soil moisture level during entire season and during vegetative stage caused a depression in plant and ear height as a result of losing turgidity and inhibition of cell enlargement. In these connections, Kramer \& Boyer (1995) stated that the plant growth is correlated by rates of cell division and enlargement. Water deficit checked or stopped cell enlargement which it inhibit the degree of cell turgor and stem and leaf elongations. Çakir (2004) found that irrigation applied at the beginning of two growth stages (vegetative and tasseling) affected plant height growth significantly. Ghooshchi et al. (2008) reported that missing one irrigation at different reproductive growth stages significantly reduced plant height and plant leaf area as compared with the control. They stated that the depression in these growth parameters as results of water deficits may effect on the loss of turgor which affects the rate of cell division and enlargement. Such result is 
in agreement with those of Aydinsakir et al. (2013), Farré \& Faci (2009) and Pandey et al. (2000).

Irrigation regime during different growth stages had a significant effect on ear dimensions (length and diameter) in both seasons (Table 6). Plants irrigated at $50 \%$ DAM during entire season or during the reproductive stage I VT-R3 $\left(\mathrm{I}_{\mathrm{HHH}}, \mathrm{I}_{\mathrm{HHL}}, \mathrm{I}_{\mathrm{LHH}}\right.$ and $\mathrm{I}_{\mathrm{LHL}}$ ) produced significantly longer and thicker ears than those irrigated at $65 \%$ DAM during this growth period $\left(\mathrm{I}_{\mathrm{HLH}}, \mathrm{I}_{\mathrm{HLL}}, \mathrm{I}_{\mathrm{LLH}}\right.$ and $\left.\mathrm{I}_{\mathrm{LLL}}\right)$ in the two seasons.

Data indicated that increasing available soil moisture in root zone during ear formation resulted in substantially increase in ear dimensions. The decrease in ear diameter and length may be assigned to the reduction of photosynthetic assimilation under drought stress (Bänziger et al., 2000). Our results are coincidence with findings by Aydinsakir et al. (2013), Kebede et al. (2014) and Moosavi (2012).

TABLE 6. Plant height, ear height, ear dimensions and number of kernels/ear of hybrid maize cv. SC10 as affected by irrigation regime at different growth sages in 2012 and 2013 seasons.

\begin{tabular}{|c|c|c|c|c|c|c|c|c|}
\hline \multirow[b]{2}{*}{$\begin{array}{l}\text { Irrigation } \\
\text { treatments }\end{array}$} & \multicolumn{3}{|c|}{ Growth stages } & \multirow{2}{*}{$\begin{array}{c}\text { Plant } \\
\text { height } \\
(\mathrm{cm})\end{array}$} & \multirow{2}{*}{$\begin{array}{c}\text { Ear } \\
\text { height } \\
(\mathbf{c m})\end{array}$} & \multirow{2}{*}{$\begin{array}{c}\text { Ear } \\
\text { length } \\
(\mathrm{cm})\end{array}$} & \multirow{2}{*}{$\begin{array}{c}\text { Ear } \\
\text { diameter } \\
(\mathbf{c m})\end{array}$} & \multirow[b]{2}{*}{$\begin{array}{c}\text { Kernels } \\
\text { (No/ear) }\end{array}$} \\
\hline & $\mathbf{S}_{\mathbf{1}}$ & $\mathbf{S}_{2}$ & $\mathbf{S}_{\mathbf{3}}$ & & & & & \\
\hline \multicolumn{9}{|c|}{ Season 2012} \\
\hline $\mathrm{I}_{\mathrm{HHH}}$ & $\mathrm{H}$ & $\mathrm{H}$ & $\mathrm{H}$ & $286.0 \mathrm{a}$ & $160.0 \mathrm{a}$ & $21.75 \mathrm{a}$ & $5.36 \mathrm{a}$ & $567 \mathrm{a}$ \\
\hline $\mathrm{I}_{\mathrm{HHL}}$ & $\mathrm{H}$ & $\mathrm{H}$ & $\mathrm{L}$ & $283.9 \mathrm{a}$ & $157.9 \mathrm{ab}$ & $21.64 \mathrm{a}$ & $5.29 \mathrm{a}$ & $557 \mathrm{a}$ \\
\hline $\mathrm{I}_{\mathrm{HLH}}$ & $\mathrm{H}$ & $\mathrm{L}$ & $\mathrm{H}$ & $280.8 \mathrm{ab}$ & $156.8 \mathrm{ab}$ & $20.71 \mathrm{~b}$ & $5.06 \mathrm{~b}$ & $499 \mathrm{~b}$ \\
\hline $\mathrm{I}_{\mathrm{HLL}}$ & $\mathrm{H}$ & $\mathrm{L}$ & $\mathrm{L}$ & $277.6 \mathrm{abc}$ & $152.6 \mathrm{bc}$ & $20.6 \mathrm{~b}$ & $4.91 \mathrm{~b}$ & $483 \mathrm{~b}$ \\
\hline $\mathrm{I}_{\mathrm{LHH}}$ & $\mathrm{L}$ & $\mathrm{H}$ & $\mathrm{H}$ & $272.4 \mathrm{bc}$ & $146.3 \mathrm{~cd}$ & $21.54 \mathrm{a}$ & $5.28 \mathrm{a}$ & $546 a$ \\
\hline $\mathrm{I}_{\mathrm{LHL}}$ & $\mathrm{L}$ & $\mathrm{H}$ & $\mathrm{L}$ & $271.1 \mathrm{c}$ & $148.5 \mathrm{~cd}$ & $21.43 \mathrm{a}$ & $5.26 \mathrm{a}$ & $540 \mathrm{a}$ \\
\hline $\mathrm{I}_{\mathrm{LLH}}$ & $\mathrm{L}$ & $\mathrm{L}$ & $\mathrm{H}$ & $262.1 \mathrm{~d}$ & $142.6 \mathrm{~d}$ & $20.09 \mathrm{~b}$ & $4.68 \mathrm{c}$ & $444 c$ \\
\hline $\mathrm{I}_{\mathrm{LLL}}$ & $\mathrm{L}$ & $\mathrm{L}$ & $\mathrm{L}$ & $255.1 \mathrm{~d}$ & $135.2 \mathrm{e}$ & $19.89 \mathrm{c}$ & $4.14 \mathrm{~d}$ & $418 \mathrm{c}$ \\
\hline F test & & & & $*$ & $* *$ & $* *$ & $*$ & $* *$ \\
\hline \multicolumn{9}{|c|}{ Season 2013} \\
\hline $\mathrm{I}_{\mathrm{HHH}}$ & $\mathrm{H}$ & $\mathrm{H}$ & $\mathrm{H}$ & $308.0 \mathrm{a}$ & $171.0 \mathrm{a}$ & $22.48 \mathrm{a}$ & $5.35 \mathrm{a}$ & $611 \mathrm{a}$ \\
\hline $\mathrm{I}_{\mathrm{HHL}}$ & $\mathrm{H}$ & $\mathrm{H}$ & $\mathrm{L}$ & $304.5 \mathrm{a}$ & $168.6 \mathrm{a}$ & $22.06 \mathrm{a}$ & $5.35 \mathrm{a}$ & $599 \mathrm{a}$ \\
\hline $\mathrm{I}_{\mathrm{HLH}}$ & $\mathrm{H}$ & $\mathrm{L}$ & $\mathrm{H}$ & $302.2 \mathrm{a}$ & $167.4 \mathrm{a}$ & $21.0 \mathrm{bc}$ & $5.01 \mathrm{~b}$ & $555 \mathrm{~b}$ \\
\hline $\mathrm{I}_{\mathrm{HLL}}$ & $\mathrm{H}$ & $\mathrm{L}$ & $\mathrm{L}$ & $302.1 \mathrm{a}$ & $165.1 \mathrm{ab}$ & $20.79 \mathrm{c}$ & $4.88 \mathrm{bc}$ & $557 \mathrm{~b}$ \\
\hline $\mathrm{I}_{\mathrm{LHH}}$ & $\mathrm{L}$ & $\mathrm{H}$ & $\mathrm{H}$ & 291.6 b & $155.6 \mathrm{c}$ & $21.85 \mathrm{a}$ & $5.26 \mathrm{a}$ & $590 \mathrm{a}$ \\
\hline $\mathrm{I}_{\mathrm{LHL}}$ & $\mathrm{L}$ & $\mathrm{H}$ & $\mathrm{L}$ & $288.1 \mathrm{~b}$ & $157.9 \mathrm{bc}$ & $21.54 \mathrm{ab}$ & $5.21 \mathrm{a}$ & $587 \mathrm{a}$ \\
\hline $\mathrm{I}_{\mathrm{LLH}}$ & $\mathrm{L}$ & $\mathrm{L}$ & $\mathrm{H}$ & $281.8 \mathrm{c}$ & $152.2 \mathrm{c}$ & $19.89 \mathrm{~d}$ & $4.81 \mathrm{c}$ & $520 \mathrm{c}$ \\
\hline $\mathrm{I}_{\text {LLL }}$ & $\mathrm{L}$ & $\mathrm{L}$ & $\mathrm{L}$ & $271.1 \mathrm{~d}$ & $143.1 \mathrm{~d}$ & $19.19 \mathrm{e}$ & $4.27 \mathrm{~d}$ & $487 \mathrm{~d}$ \\
\hline \multicolumn{4}{|c|}{$F$ test } & $* *$ & *** & *** & $* *$ & $* *$ \\
\hline
\end{tabular}

$\mathbf{S}_{\mathbf{1}}=$ Vegetative stage, started from the third leaf (V3) to onset tasseling (VT) stages; $\mathbf{S}_{\mathbf{2}}=$ Reproductive stage I started from VT to mid milk (R3) stages [including VT, silking (R1), blister (R2) and mid R3) stage]; $\mathbf{S}_{\mathbf{3}}=$ Reproductive stage II started from mid R3 to physiological maturity (R6) [including dough (R4) and dent (R5) stages].

$\mathbf{H}=$ irrigation at $50 \%$ depletion of the available soil moisture (DAM); $\mathbf{L}=$ irrigation at $65 \%$ DAM.

$*$ and $* *$ indicate $\mathrm{P}<0.05$ and $\mathrm{P}<0.01$. Means in each column designated by the same latter are not significantly different at $5 \%$ level using Duncan's Multiple Range Test.

Yield attributes

Egypt. J. Agron. 38, No. 3 (2016) 
The irrigation level during different growth stages gave significantly effect on number of kernels per ear in the two seasons (Table 6). $\mathrm{I}_{\mathrm{HHH}}$ treatment produced significantly greater number of kernels per ear than $I_{L L L}$ treatment in the two seasons. Number of kernels per ear produced by maize plants which received high soil moisture during the reproductive stage I VT-R3 $\left(\mathrm{I}_{\mathrm{HHL}}, \mathrm{I}_{\mathrm{LHH}}\right.$ and $\mathrm{I}_{\mathrm{LHL}}$ ) or during entire season $\left(\mathrm{I}_{\mathrm{HHH}}\right)$ was practically the same. Number of kernels per ear was increased by increasing available soil moisture in root zone during entire season or during VT-R3 stage. This may be attributed to increase ear diameter and length. In this regard, Yilmaz et al. (2010) concluded that water stress at tasseling stages and milk stages decreased the kernel set on the ear. Aydinsakir et al. (2013) observed that the deficit in soil water content in flowering stage resulted in delayed silk emergence and their growth upsets, so anthesis-silking interval increased in water deficit treatments greatly. They add that delayed silk emergence caused non-simultaneous pollination and silking. Song-Feng et al. (1998) showed that water deficit led to slower pollen and filament development, reduced filament fertility and caused a reduction in grain number per ear. This result supported the works of Çakir (2004), Ge et al. (2012) and Kebede et al. (2014).

Data in Table 7 show that 100-grain weight was significantly heavier in all treatments receiving irrigation at 50\% DAM during VT-R3 or R3-stage $\left(\mathrm{I}_{\mathrm{HHH}}\right.$, $\mathrm{I}_{\mathrm{HHL}}, \mathrm{I}_{\mathrm{HLH}}, \mathrm{I}_{\mathrm{LHH}}$ and $\mathrm{I}_{\mathrm{LHL}}$ ) than irrigation at $65 \%$ DAM during entire season in both seasons. Thus, sufficient soil moisture in the root zone through irrigation at $50 \%$ DAM during entire season or during reproductive stage increased the capacity of maize plants to accumulate dry matter through the increase in the area of photosynthesizing leaves which in turn resulted in more photo-synthetics available for filling grains. In this connection, Yilmaz et al. (2010) stated that kernel weight of full irrigation and irrigation until milk stage treatments was higher even than in the other treatments showed the determinative effect of water availability in soil during the period for the coming grain filling. Aydinsakir et al. (2013) reported that low level of available water cause reduction in the 1000 grain weight resulted in low transition of photosynthesis matter and assimilates to kernels. These results are in close agreement with those of Çakir (2004), Ge et al. (2012) and Kuşçu \& Demir (2012).

Irrigation regime during different growth stages had a significant effect on grain weight per ear in the two seasons (Table 7). Plants irrigated at $50 \%$ DAM during entire season produced the heaviest grain weight per ear, while those irrigated at $65 \%$ DAM during entire season produced the lowest one in both seasons. No significant difference in grain weight per ear was evidenced among all treatments receiving irrigation at $50 \%$ DAM during the reproductive stage I VT-R3 or entire season in both seasons. Such increase in grain weight per ear obtained from sufficient soil moisture in the root zone during entire season or during the reproductive stage I VT-R3 may be due to the considerable increase in dry matter accumulation, leaf area index, crop growth rate and net assimilation rate which reflected in the higher number of kernels per ear and kernel weight

Egypt. J. Agron . 38, No.3 (2016) 
and in turn increased grain weight per ear. Similar results were obtained by Borrás et al. (2003), Çakir (2004) and Kebede et al. (2014)

TABLE 7. Grain yield, grain weight/ear, shelling $\%$ and 100 -grain weight of hybrid maize cv. SC10 as affected by irrigation regime at different growth sages in 2012 and 2013 seasons.

\begin{tabular}{|c|c|c|c|c|c|c|c|c|c|c|c|}
\hline \multirow{2}{*}{$\begin{array}{c}\text { Irrigation } \\
\text { treatments }\end{array}$} & \multicolumn{3}{|c|}{$\begin{array}{l}\text { Growth } \\
\text { stages }\end{array}$} & \multicolumn{2}{|c|}{$\begin{array}{l}\text { Grain weight } \\
\text { (g/ear) }\end{array}$} & \multicolumn{2}{|c|}{$\begin{array}{c}\text { Shelling } \\
(\%)\end{array}$} & \multicolumn{2}{|c|}{$\begin{array}{l}\text { 100-grain } \\
\text { weight(g) }\end{array}$} & \multicolumn{2}{|c|}{$\begin{array}{c}\text { Grain yield } \\
\text { (ton/ha) }\end{array}$} \\
\hline & $S_{1}$ & $\mathbf{S}_{2}$ & $\mathbf{S}_{3}$ & 2012 & 2013 & 2012 & 2013 & 2012 & 2013 & 2012 & 2013 \\
\hline $\mathrm{I}_{\mathrm{HHH}}$ & $\mathrm{H}$ & $\mathrm{H}$ & $\mathrm{H}$ & $249.0 \mathrm{a}$ & $283.1 \mathrm{a}$ & $80.38 \mathrm{a}$ & $81.92 \mathrm{a}$ & $43.91 \mathrm{a}$ & $46.33 \mathrm{a}$ & $10.14 \mathrm{a}$ & $10.93 \mathrm{a}$ \\
\hline $\mathrm{I}_{\mathrm{HHL}}$ & $\mathrm{H}$ & $\mathrm{H}$ & $\mathrm{L}$ & $239.3 \mathrm{a}$ & $270.8 \mathrm{ab}$ & $79.72 \mathrm{a}$ & $80.77 \mathrm{ab}$ & $42.97 \mathrm{ab}$ & $45.21 \mathrm{a}$ & $9.90 \mathrm{a}$ & $10.58 \mathrm{a}$ \\
\hline $\mathrm{I}_{\mathrm{HLH}}$ & $\mathrm{H}$ & $\mathrm{L}$ & $\mathrm{H}$ & $216.6 \mathrm{ab}$ & 251.3abc & $78.86 \mathrm{ab}$ & $79.79 \mathrm{ab}$ & $43.41 \mathrm{ab}$ & $45.28 \mathrm{a}$ & $9.43 \mathrm{a}$ & $10.14 \mathrm{a}$ \\
\hline $\mathrm{I}_{\mathrm{HLL}}$ & $\mathrm{H}$ & $\mathrm{L}$ & $\mathrm{L}$ & $196.7 \mathrm{bc}$ & $240.1 \mathrm{bc}$ & $77.56 \mathrm{bc}$ & $79.68 \mathrm{ab}$ & $40.72 \mathrm{c}$ & $43.11 \mathrm{~b}$ & $8.13 b c$ & $8.94 \mathrm{~b}$ \\
\hline $\mathrm{I}_{\mathrm{LHH}}$ & $\mathrm{L}$ & $\mathrm{H}$ & $\mathrm{H}$ & $238.2 \mathrm{a}$ & $272.5 \mathrm{a}$ & $79.36 \mathrm{a}$ & $80.22 \mathrm{ab}$ & $43.62 \mathrm{ab}$ & $46.18 \mathrm{a}$ & $9.89 \mathrm{a}$ & $10.58 \mathrm{a}$ \\
\hline $\mathrm{I}_{\mathrm{LHL}}$ & $\mathrm{L}$ & $\mathrm{H}$ & $\mathrm{L}$ & $229.8 \mathrm{a}$ & 263.0abc & $79.12 \mathrm{a}$ & $79.97 \mathrm{ab}$ & $42.56 \mathrm{~b}$ & $44.8 \mathrm{ab}$ & $9.45 \mathrm{a}$ & $10.35 \mathrm{a}$ \\
\hline $\mathrm{I}_{\text {LLH }}$ & $\mathrm{L}$ & $\mathrm{L}$ & $\mathrm{H}$ & $190.2 \mathrm{bc}$ & $233.2 \mathrm{c}$ & $77.51 \mathrm{bc}$ & $78.84 \mathrm{bc}$ & $42.83 \mathrm{ab}$ & $44.84 \mathrm{ab}$ & $8.65 b$ & $9.02 \mathrm{~b}$ \\
\hline $\mathrm{I}_{\text {LLL }}$ & $\mathrm{L}$ & $\mathrm{L}$ & $\mathrm{L}$ & $164.9 \mathrm{c}$ & $199.7 \mathrm{~d}$ & $77.31 \mathrm{c}$ & $78.01 \mathrm{c}$ & $39.44 \mathrm{~d}$ & $41.01 \mathrm{c}$ & $7.52 \mathrm{c}$ & $7.93 \mathrm{c}$ \\
\hline F test & & & & $* *$ & $*$ & ** & $*$ & $*$ & $* *$ & $* *$ & *** \\
\hline
\end{tabular}

$\mathbf{S}_{1}=$ Vegetative stage, started from the third leaf (V3) to onset tasseling (VT) stages; $\mathbf{S}_{2}=$ Reproductive stage I started from VT to mid milk (R3) stages [including VT, silking (R1), blister (R2) and mid R3) stage]; $\mathbf{S}_{\mathbf{3}}=$ Reproductive stage II started from mid R3 to physiological maturity (R6) [including dough (R4) and dent (R5) stages].

$\mathbf{H}=$ irrigation at $50 \%$ depletion of the available soil moisture (DAM); $\mathbf{L}=$ irrigation at $65 \% \mathrm{DAM}$

$*$ and $* *$ indicate $\mathrm{P}<0.05$ and $\mathrm{P}<0.01$. Means in each column designated by the same latter are not significantly different at 5\% level using Duncan's Multiple Range Test.

Data in Table 7 show that irrigation treatments $\mathrm{I}_{\mathrm{HHH}}, \mathrm{I}_{\mathrm{HHL}}, \mathrm{I}_{\mathrm{HLH}}, \mathrm{I}_{\mathrm{LHH}}$ and $\mathrm{I}_{\mathrm{LHL}}$ though not significantly different, resulted in a substantial increase in shelling percentage compared with $\mathrm{I}_{\mathrm{LLL}}$ treatment in the two seasons. Plants irrigated at $50 \%$ DAM during entire season exhibited the highest shelling percentage, while those irrigated at $65 \%$ DAM during entire season exhibited the lowest one. Such increase in shelling percentage obtained from sufficient soil moisture in the root zone at the mentioned stages may be attributed to improved plant growth and in turn increased grain filling and grain weight per ear. These results are in agreement with the findings of Abayomi et al. (2012), Khoshvaghti et al. (2013) and Zaki et al. (2014).

\section{Grain yield}

Data in Table 7 show that irrigation regime during different growth stages had significant effect on grain yield per hectare in both seasons. Plants irrigated at $50 \%$ DAM during entire season $\left(\mathrm{I}_{\mathrm{HHH}}\right)$ out yielded those irrigated at $65 \%$ DAM $\left(\mathrm{I}_{\mathrm{LLL}}\right)$ in grain yield per hectare in both seasons. Application of $(\mathrm{L})$ level at $\mathrm{S}_{1}$ and $\mathrm{S}_{3}\left(\mathrm{I}_{\mathrm{LHH}}\right.$ and $\left.\mathrm{I}_{\mathrm{LHL}}\right)$ did not cause significant yield reduction in the two seasons (Table 7). Plants receiving irrigation at 50\% DAM during entire season $\left(\mathrm{I}_{\mathrm{HHH}}\right)$ or during $\mathrm{S}_{2}$ stage $\left(\mathrm{I}_{\mathrm{HHL}}, \mathrm{I}_{\mathrm{LHH}}\right.$ and $\left.\mathrm{I}_{\mathrm{LHL}}\right)$ practically produced the same grain yield and significantly surpassed those receiving irrigation at 65\% DAM during these stages $\left(\mathrm{I}_{\mathrm{HLL}}, \mathrm{I}_{\mathrm{LLH}}, \mathrm{I}_{\mathrm{LLL}}\right)$ in both seasons. The treatment receiving low irrigation level during entire season $\left(\mathrm{I}_{\mathrm{LLL}}\right)$ recorded the lowest values of grain yield in the two seasons. 
Figure 1 illustrated that irrigation at $65 \%$ instead of $50 \%$ DAM during any growth stage resulted in a decrease in grain yield than Irrigation at 50\% DAM during entire season $\left(\mathrm{I}_{\mathrm{HHH}}\right)$ in both seasons. The decrease in grain yield was ranged from 2.3 to $3.1 \%$ for $\mathrm{I}_{\mathrm{HHL}}, 7$ to $7.2 \%$ for $\mathrm{I}_{\mathrm{HLH}}, 19.8$ to $18.2 \%$ for $\mathrm{I}_{\mathrm{HLL}}, 2.4$ to $3.2 \%$ for $\mathrm{I}_{\mathrm{LHH}}, 6.8$ to $5.3 \%$ for $\mathrm{I}_{\mathrm{LHL}}, 14.7$ to $17.4 \%$ for $\mathrm{I}_{\mathrm{LLH}}$ and 25.8 to $27.5 \%$ for $\mathrm{I}_{\mathrm{LLL}}$ treatments in both seasons, respectively. Figure 1 also shows that irrigation at $65 \%$ DAM during entire season $\left(\mathrm{I}_{\mathrm{LLL}}\right)$ recorded the highest reduction percentage in grain yield followed by $\mathrm{I}_{\mathrm{HLL}}$ and $\mathrm{I}_{\mathrm{LLH}}$ in both seasons. The increase in grain yield at high soil moisture applied during the entire season or from beginning tasseling to mid-milk stage may be attributed to better early growth, viz LAI, dry weight per plant, CGR, plant height, ear length and ear diameter which were reflected in the significantly higher values of yield components viz. number of kernel per ear, ear kernels weight and 100-grain weight and ultimately grain yield.

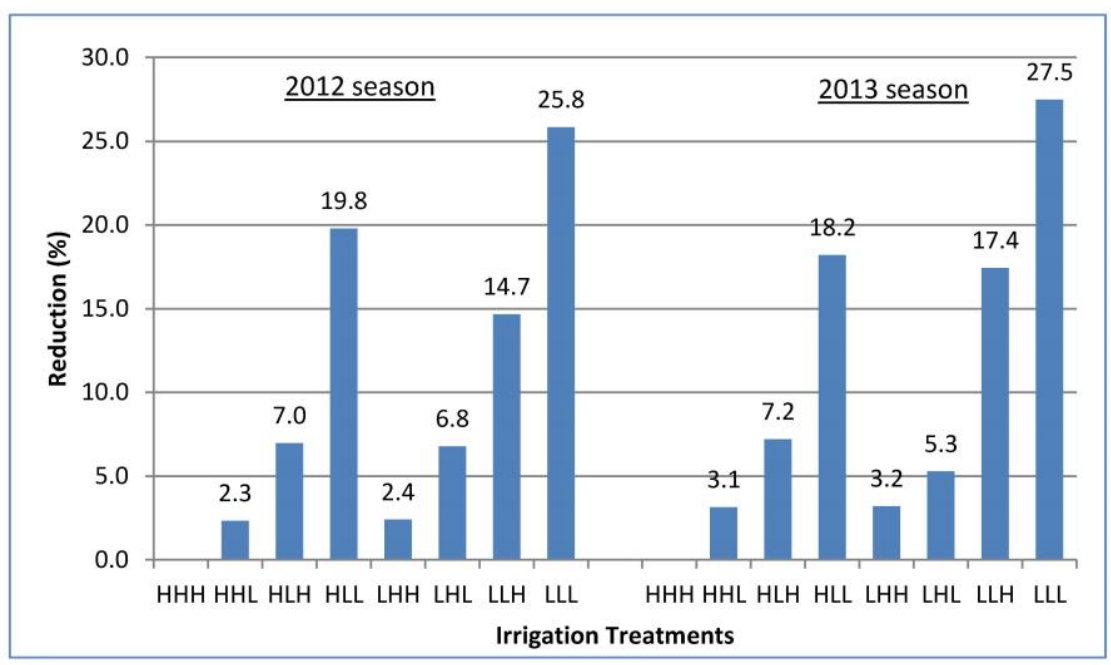

Fig. 1. Reduction percentage in grain yield due to application low irrigation regime (L) during different growth stages compared with application high irrigation regime $(\mathrm{H})$ during entire seasons in 2012 and 2013 seasons.

In this connection, Yilmaz et al. (2010) found that stress conditions created at early vegetative and after milk stage did not cause significant yield decrease. They stated that when the water stress imposed at the tasseling (before and after tasseling), the yield decrease was $29.1 \%$ parallel with the results of irrigation water saving $16.0 \%$ based on averages of two years. Khalili et al. (2013)reported that water deficit during productivity stage can cause severe reduction in yield and yield components of corn cultivars. Aydinsakir et al. (2013) showed that corn can grow under water deficit (moderate level) without significant reduction in the amount of grain yield.

Egypt. J. Agron . 38, No.3 (2016) 
These results are in harmony with those of Farré \& Faci( 2009), Ge et al. (2012), Igbadun et al.( 2008) and Khalili et al.( 2013).

\section{Some water relations}

Seasonal applied irrigation water and stored water

Amount of applied irrigation water (AW) and stored water (SW) from sowing to harvest as affected by irrigation regime during different growth stages of maize are presented in Table $8 . \mathrm{I}_{\mathrm{HHH}}$ treatment recorded the highest values of applied water 7286 and $7321 \mathrm{~m}^{3} /$ hectare and stored water 5090 and $5148 \mathrm{~m}^{3} /$ hectare, while $\mathrm{I}_{\text {LLL }}$ treatment recorded the lowest values 6171 and $6198 \mathrm{~m}^{3} /$ hectare and stored water 3990 and $4021 \mathrm{~m}^{3} /$ hectare in the 2012 and 2013 seasons, respectively. Data indicated that amount of stored water was related with amount of applied water in both seasons. Such increase in the amount of applied water by increasing the level of irrigation water may be attributed to considerable increase in leaf area, which resulted in a greater transpiration and in turn water requirement.

TABLE8. Seasonal irrigation water applied (WA), water stored (WS) and water consumptive use (WCU) as affected by irrigation regime at different growth sages in 2012 and 2013 seasons.

\begin{tabular}{|c|c|c|c|c|c|c|c|c|c|c|c|}
\hline \multirow{2}{*}{$\begin{array}{l}\text { Irrigation } \\
\text { treatments }\end{array}$} & \multicolumn{3}{|c|}{ Growth stages } & \multicolumn{2}{|c|}{ WA $\left(\mathbf{m}^{3} / \mathbf{h a}\right)$} & \multicolumn{2}{|c|}{$\begin{array}{c}\text { Saving water } \\
\left(\mathbf{m}^{3}\right)\end{array}$} & \multicolumn{2}{|c|}{ WS $\left(\mathbf{m}^{3} / \mathrm{ha}\right)$} & \multicolumn{2}{|c|}{$\begin{array}{c}\text { WCU } \\
\left(\mathbf{m}^{3} / \mathbf{h a}\right)\end{array}$} \\
\hline & $\mathbf{S}_{1}$ & $\mathbf{S}_{2}$ & $\mathbf{S}_{3}$ & 2012 & 2013 & 2012 & 2013 & 2012 & 2013 & 2012 & 2013 \\
\hline $\mathrm{I}_{\mathrm{HHH}}$ & $\mathrm{H}$ & $\mathrm{H}$ & $\mathrm{H}$ & 7286 & 7321 & - & - & 5090 & 5148 & 4857 & 4860 \\
\hline $\mathrm{I}_{\mathrm{HHL}}$ & $\mathrm{H}$ & $\mathrm{H}$ & $\mathrm{L}$ & 6781 & 6802 & 505 & 519 & 4424 & 4633 & 4517 & 4538 \\
\hline $\mathrm{I}_{\mathrm{HLH}}$ & $\mathrm{H}$ & $\mathrm{L}$ & $\mathrm{H}$ & 6667 & 6714 & 619 & 607 & 4490 & 4543 & 4398 & 4448 \\
\hline $\mathrm{I}_{\mathrm{HLL}}$ & $\mathrm{H}$ & $\mathrm{L}$ & $\mathrm{L}$ & 6495 & 6514 & 790 & 807 & 4314 & 4336 & 4221 & 4240 \\
\hline $\mathrm{I}_{\mathrm{LHH}}$ & $\mathrm{L}$ & $\mathrm{H}$ & $\mathrm{H}$ & 6571 & 6593 & 714 & 729 & 4393 & 4417 & 4357 & 4369 \\
\hline $\mathrm{I}_{\mathrm{LHL}}$ & $\mathrm{L}$ & $\mathrm{H}$ & $\mathrm{L}$ & 6398 & 6424 & 888 & 898 & 4219 & 4248 & 4126 & 4152 \\
\hline $\mathrm{I}_{\text {LLH }}$ & $\mathrm{L}$ & $\mathrm{L}$ & $\mathrm{H}$ & 6345 & 6362 & 940 & 960 & 4167 & 4190 & 4074 & 4095 \\
\hline $\mathrm{I}_{\text {LLL }}$ & $\mathrm{L}$ & $\mathrm{L}$ & $\mathrm{L}$ & 6171 & 6198 & 1114 & 1124 & 3990 & 4021 & 3898 & 3926 \\
\hline
\end{tabular}

Data in Table 8 and Fig. 2 illustrated that Irrigation at 65\% DAM instead of $50 \%$ DAM during any growth stage resulted in a substantially reduce in amount of applied water than irrigation at 50\% DAM during entire season. The mentioned treatments saved from 505 to $1114 \mathrm{~m}^{3}$ applied water in the first season and from 519 to $1124 \mathrm{~m}^{3}$ in the second season than $\mathrm{I}_{\mathrm{HHH}}$ treatment (Table 8). However, percentages of saving water obtained from low irrigation level during different growth stages were ranged from 11.3 to $25 \%$ in the first season and from 11.6 to $25.2 \%$ in the second season than high irrigation level (Fig. 2).

Egypt. J. Agron. 38, No. 3 (2016) 
Although, the irrigation treatments $\mathrm{I}_{\mathrm{HHL}}, \mathrm{I}_{\mathrm{HLH}}, \mathrm{I}_{\mathrm{LHH}}$ and $\mathrm{I}_{\mathrm{LHL}}$ were equivalent to $\mathrm{I}_{\mathrm{HHH}}$ in growth and grain yield, they were lower in amount of applied irrigation water. They saved at least 11.3, 13.6, 16 and $19.9 \%$ applied water parallel with the yield decrease at the most 3.1, 7.2, 3.2 and 5.3\% than $\mathrm{I}_{\mathrm{HHH}}$ treatment, respectively. Y1lmaz et al. (2010) observed that when the water stress imposed at the tasseling (before and after tasseling), the yield decrease was $29.1 \%$ parallel with the results of irrigation water saving $16.0 \%$ based on averages of two years.

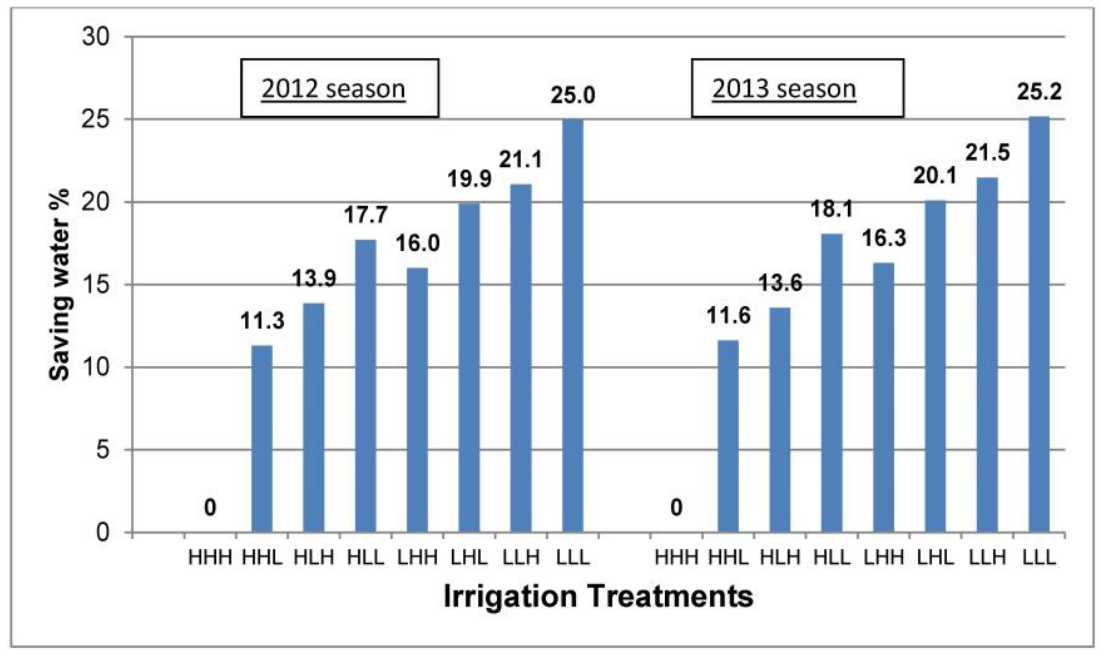

Fig. 2. Saving water percentage based on $\mathbf{I}_{\mathrm{HHH}}$ as affected by irrigation regime during different growth stages in 2012 and 2013 seasons.

\section{Seasonal actual water consumptive use}

The quantities of water lost as evapotranspiration (seasonal water consumptive use) became greater by increasing the amount of applied water in both seasons (Table 8). Application of low irrigation level (L) during any growth stage $\left(S_{1}, S_{2}\right.$ and $S_{3}$ stages) resulted in a decrease in values of seasonal water consumptive use (WCU) compared with application of high irrigation level $(\mathrm{H})$ in the two seasons. $\mathrm{I}_{\mathrm{LLL}}$ treatment recorded the lowest values of seasonal water consumptive use 3898 and $3926 \mathrm{~m}^{3} /$ hectare, while $\mathrm{I}_{\mathrm{HHH}}$ recorded the highest values 4857 and $4860 \mathrm{~m}^{3} /$ hectare in the two seasons. Data indicated that seasonal water consumptive use was related positively with amount of applied water. In general, the treatment $\mathrm{I}_{\mathrm{HHH}}$ gave the highest value of actual water consumptive use, while the lowest value was $\mathrm{I}_{\mathrm{LLL}}$ treatment. High value of actual water consumptive use at $\mathrm{I}_{\mathrm{HHH}}$ treatment can be attributed to the increase in evaporation at elevated available moisture; more supplying plants with sufficient moisture led to an increase in green cover and hence increase transpiration. These results agree with those of Aydinsakir et al. (2013), Igbadun et al. 
(2008) and Pandey et al. (2000) who noticed that seasonal transpiration and evapotranspiration decreased with less seasonal water applied.

\section{Water productivity}

Water productivity ( $\mathrm{kg}$ grain $/ \mathrm{m}^{3}$ water) is considered as an evaluation parameter of yield per unit of applied or consumed water. Data in Fig. 3 and 4 illustrated that irrigation at $65 \%$ DAM during two consecutive growth stages $\left(\mathrm{I}_{\mathrm{HLL}}, \mathrm{I}_{\mathrm{LLH}}\right.$ and $\mathrm{I}_{\mathrm{LLL}}$ ) decreased WP water applied and WP wCU compared with irrigation at $50 \%$ DAM during entire season $\left(\mathrm{I}_{\mathrm{HHH}}\right)$ in the two seasons. However, irrigation at 50\% DAM during the reproductive stage I VT-R3 $\left(\mathrm{I}_{\mathrm{HHL}}, \mathrm{I}_{\mathrm{LHH}}\right.$ and $\mathrm{I}_{\mathrm{LHL}}$ treatments) and $\mathrm{I}_{\mathrm{HLH}}$ increased this respect compared with $\mathrm{I}_{\mathrm{HHH}}$ in both seasons. The $\mathrm{I}_{\mathrm{LHH}}$ and $\mathrm{I}_{\mathrm{LHL}}$ treatments recorded the highest values of water productivity, while $\mathrm{I}_{\mathrm{LLL}}$ recorded the lowest values in both seasons.

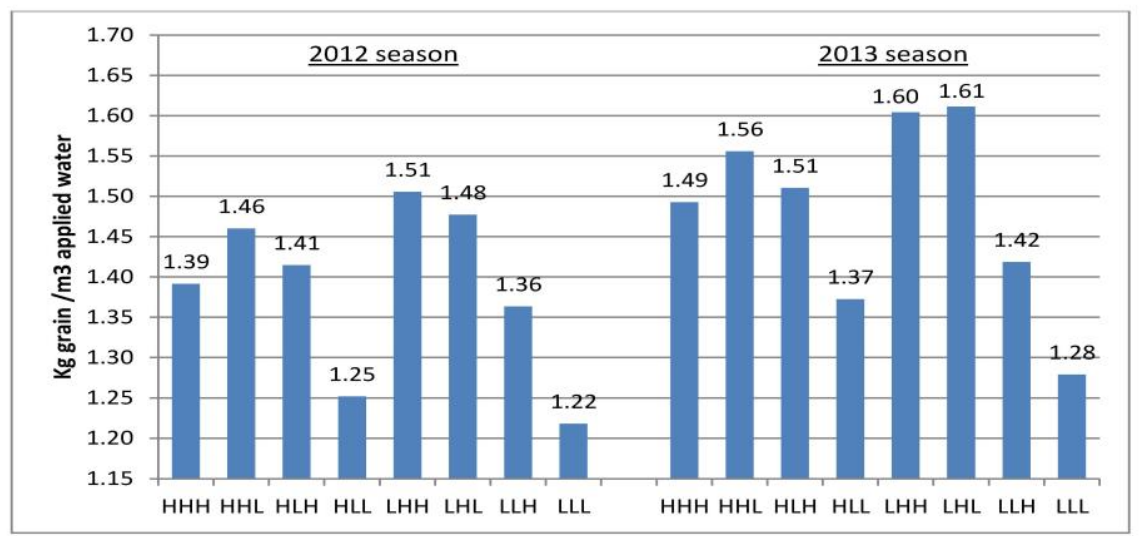

Fig. 3. Productivity of applied water as affected by irrigation regime at different growth sages in 2012 and 2013 seasons.

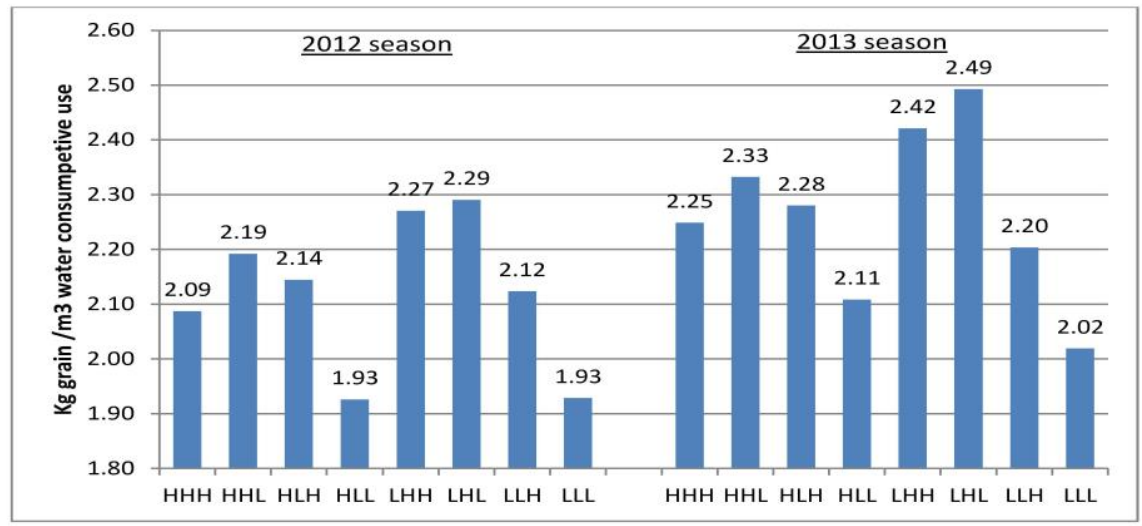

Fig. 4. Productivity of water consumptive use as affected by irrigation regime at different growth sages in 2012 and 2013 seasons.

Egypt. J. Agron. 38, No. 3 (2016) 
WP water applied was ranged from 1.51 to $1.60 \mathrm{~kg}$ grain $/ \mathrm{m}^{3} \mathrm{AW}$ for $\mathrm{I}_{\mathrm{LHH}}$, from 1.48 to $1.61 \mathrm{~kg}$ grain $/ \mathrm{m}^{3} \mathrm{AW}$ for $\mathrm{I}_{\mathrm{LHL}}$ and from 1.22 to $1.28 \mathrm{~kg}$ grain $/ \mathrm{m}^{3} \mathrm{AW}$ for $\mathrm{I}_{\mathrm{LLL}}$ in the two seasons. WP ${ }_{\mathrm{WCU}}$ was ranged from 1.51 to $1.60 \mathrm{~kg}$ grain $/ \mathrm{m}^{3} \mathrm{WCU}$ for $\mathrm{I}_{\mathrm{LHH}}$, from 1.48 to $1.61 \mathrm{~kg}$ grain $/ \mathrm{m}^{3} \mathrm{WCU}$ for $\mathrm{I}_{\mathrm{LHL}}$ and from 1.22 to $1.28 \mathrm{~kg}$ grain $/ \mathrm{m}^{3}$ WCU for $\mathrm{I}_{\mathrm{LLL}}$ in the two seasons. The increase in water productivity for $\mathrm{I}_{\mathrm{LHH}}$ and $\mathrm{I}_{\mathrm{LHL}}$ treatments may be due to the high grain yield and less amount of applied water and water consumptive use. The $\mathrm{I}_{\mathrm{LHH}}$ and $\mathrm{I}_{\mathrm{LHL}}$ treatments were statistically at par with the $\mathrm{I}_{\mathrm{HHH}}$ treatment in high grain yield and they were lower than them in amount of applied irrigation water and water consumptive use. Kebede et al. (2014) reported that the $50 \%$ of field capacity treatments were higher $100 \%$ and the $75 \%$ FC treatments at the V14, R1 and R3 stages. Aydinsakir et al. (2013) found that the highest water use efficiency obtained from $50 \%$ water applied treatment. Yenesew \&Tilahun (2009) reported that $75 \%$ deficit water treatment gave higher water use efficiency from $75 \%$ deficit treatment than stressing by 50\% deficit. Djaman (2011) stated that $60 \%$ of fully irrigated treatment resulted in the highest irrigation water use efficiency.

\section{Crop coefficient $(\mathrm{Kc})$}

Effect of crop characteristics, climatic conditions and irrigation frequency on crop water requirements is indicated by the crop coefficient $(\mathrm{Kc})$ which represents the relationship between reference potential $\left(\mathrm{ET}_{0}\right)$ and actual crop evapotranspiration (ETA). Results of calculated values of crop coefficient (K) from the best irrigation treatment $\left(\mathrm{I}_{\mathrm{LHL}}\right)$ are shown in Table 9.

TABLE 9. Computed empirical coefficient (Kc) of maize cv. SC 10 for the best treatment in both seasons.

\begin{tabular}{|l|c|c|c|c|c|c|}
\hline \multirow{2}{*}{$\begin{array}{l}\text { Growth } \\
\text { stage }\end{array}$} & $\begin{array}{c}\text { Actual } \\
\text { WCU } \\
\text { (mm/day) }\end{array}$ & $\begin{array}{c}\text { 2012 season } \\
\text { Penman } \\
\text { monteith (ET } \\
\text { in mm/day) }\end{array}$ & Kc & $\begin{array}{c}\text { Actual } \\
\text { WCU } \\
\text { (mm/day) }\end{array}$ & $\begin{array}{c}\text { Penman } \\
\text { monteith } \\
\left(\mathbf{E T} \mathbf{T}_{\mathbf{0}} \mathbf{i n m m} \text { /d }\right. \\
\text { ay) }\end{array}$ & Kc \\
\hline Emergence & 3.60 & 7.17 & 0.50 & 1.46 & 4.06 & 0.36 \\
Vegetative & 3.88 & 6.44 & 0.60 & 3.18 & 6.81 & 0.47 \\
VT-R3 & 3.97 & 6.26 & 0.63 & 4.19 & 6.49 & 0.65 \\
R3-R5 & 2.85 & 5.20 & 0.55 & 3.73 & 6.02 & 0.62 \\
R5-R6 & 1.57 & 3.15 & 0.50 & 4.11 & 7.83 & 0.52 \\
\hline
\end{tabular}

VT= Tasseling, R3=Milk, R5= Dent and R6= maturity stages.

Figure 5 shows that $\mathrm{Kc}$ value increased gradually from emergence until the reproductive stage I from onset tasseling to med-milk stage (VT-R3) and then decreased in both seasons. The maximum Kc value was at VT-R3 stage (viz. tasseling, silking, blister and mid-milk stages). This was expected because of the fast elongation and the peak of dry matter accumulation occurred during this stage. The above mentioned stage is critical and has been shown to have the highest water requirement for maize. The high soil moisture level was adapted in the present study during this stage in which maize can be hurt the most when use exceeds supply. 


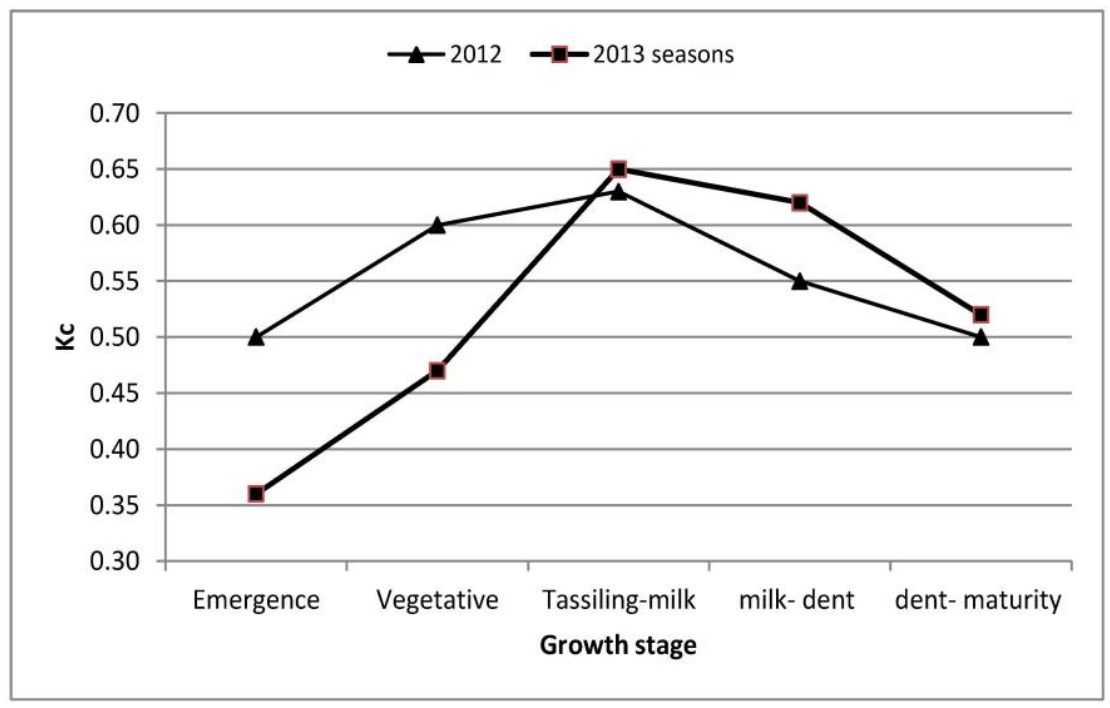

Fig.5. Computed empirical coefficient (Kc) of maize cv. SC 10 for the best treatment in both seasons.

The values of $\mathrm{Kc}$ for the best treatment $\left(\mathrm{I}_{\mathrm{LHL}}\right)$ according the Penman Monteith equation were $050,0.60,0.63,0.55$ and 0.50 for the growth stages emergence, vegetative-tasseling, tasseling-milk, milk- dent and dent- maturity stages, respectively in the first season, while these values were $0.36,0.47,0.65$, 0.62 and 0.52 in the second season. The maximum value throughout the two seasons was during from onset tasseling to mid milk stages.

At North Delta, Penman Monteith equation can be used in determining the actual consumptive use and the average of crop Coefficient $(\mathrm{Kc})$ for the two seasons was found to be $0.43,0.54,0.64,0.58$ and 0.51 during emergence, vegetative-tasseling, tasseling-milk, milk- dent and dent- maturity stages, respectively. Gao et al. (2009) reported that crop Coefficient of maize varied at different growth stages, at initial, mid and late from $0.36-0.37,1.18-1.19$ to 0.22 0.28 , respectively. Djaman (2011) found that the Kc values and their magnitude gradually decreased with decreasing irrigation amounts. These results agree with Jiang et al. (2014), Li et al. (2008) and Williams \& Ayars (2005).

\section{Conclusion}

It can be concluded that irrigation at $65 \%$ DAM during vegetative stage followed 50\% DAM during VT-R3 stage and 65\% DAM during reminder season $\left(\mathrm{I}_{\mathrm{LHL}}\right)$ was the best treatment which resulted in high grain yield with less amount of applied irrigation water and consumptive use in Kafr El-Shiekh Governorate. 


\section{Rreferences}

Abayomi, Y., Awokola, C. and Lawal, Z. (2012) Comparative evaluation of water deficit tolerance capacity of extra-early and early maize genotypes under controlled conditions. J. Agric. Sci. 4, 54.

Allen, R. G., Pereira, L. S., Raes, D. and Smith, M. (1998) Crop evapotranspirationGuidelines for computing crop water requirements-FAO Irrigation and drainage paper 56. FAO, Rome, 300, D05109.

Aydinsakir, K., Erdal, S., Buyuktas, D., Bastug, R. and Toker, R. (2013) The influence of regular deficit irrigation applications on water use, yield, and quality components of two corn (Zea mays L.) genotypes.Agric. Water Manage. 128, 65-71.

Bahadori, A., Mobasser, H. R. and Ganjali, H. R. (2015) Influence of water stress and plant density on some characteristics in corn. In "Biological Forum", Vol. 7, pp. 673. Research Trend.

Bänziger, M., Edmeades, G. O., Beck, D. and Bellon, M. (2000) Breeding for drought and nitrogen stress tolerance in maize: From theory to practice. In. Taller Internacional Sobre Bajo Fósforo en el Cultivo de Frijol. 13-15 Nov 1995San José (Costa Rica)". CIMMYT, México, DF (México).

Black, C. A., Evans, D. and Dinauer, R. (1965) Methods of Soil Analysis, American Society of Agronomy Madison, WI.

Borrás, L., Westgate, M. and Otegui, M. (2003) Control of kernel weight and kernel water relations by post - flowering source-sink ratio in maize. Ann. Bot. 91, 857-867.

Çakir, R. (2004) Effect of water stress at different development stages on vegetative and reproductive growth of corn. Field Crops Res. 89, 1-16.

Djaman, K. (2011) Crop evapotranspiration, crop coefficients, plant growth and yield parameters, and nutrient uptake dynamics of maize (Zea mays L.) under full and limited irrigation. Ph.D. Thesis, University of Nebraska-Lincoln,USA.

Duncan, D. B. (1955) Multiple range and multiple F tests. Biometrics, 11, 1-42.

El-Bably, A. Z., Abd El-Hafez, S. A., Mahmoud, M. A. and Oud, S. A. H. (2015) A new conceptual framework for water conservation based on addressing water balance, crop rotation and economics. Int. J. Water Res. Environ. Eng. 4, 120-127.

FAO (2014). FAOSTAT. http://fenix.fao.org/faostat/beta/en/\#data/QC.

Farré, I. and Faci, J.M. (2009) Deficit irrigation in maize for reducing agricultural water use in a Mediterranean environment. Agric. Water Manage. 96, 383-394.

Gao, Y., Duan, A., Sun, J., Li, F., Liu, Z., Liu, H. and Liu, Z. (2009) Crop coefficient and water-use efficiency of winter wheat/ spring maize strip intercropping. Field Crops Res. 111, 65-73. 
Ge, T., Sui, F., Bai, L., Tong, C. and Sun, N. (2012) Effects of water stress on growth, biomass partitioning, and water-use efficiency in summer maize (Zea mays L.) throughout the growth cycle.Acta Physiol. Plant. 34, 1043-1053.

Ghooshchi, F., Seilsepour, M. and Jafari, P. (2008) Effects of water stress on yield and some agronomic traits of maize [SC 301]. Am.-Eurasian J. Sustain. Agric. 4, 302-305.

Gomez, K. A. and Gomez, A. A. (1984) Statistical Procedures for Agricultural Research, John Wiley \& Sons.

Hafez, E. and Gharib, H. (2016) Effect of exogenous application of ascorbic acid on physiological and biochemical characteristics of wheat under water stress. Int. J. Plant Prod. 10, 4.

Igbadun, H. E., Salim, B. A., Tarimo, A. K. and Mahoo, H. F. (2008) Effects of deficit irrigation scheduling on yields and soil water balance of irrigated maize. Irrigation Sci. 27, 11-23.

Israelsen, B. O. and Hansen, V. E. (1962) Irrigation Principles and Practices", John Wiley and Sons, Inc, New York, USA.

Jiang, X., Kang, S., Tong, L., Li, F., Li, D., Ding, R. and Qiu, R. (2014) Crop coefficient and evapotranspiration of grain maize modified by planting density in an arid region of northwest China. Agric. Water Manage. 142, 135-143.

Kebede, H., Sui, R., Fisher, D. K., Reddy, K. N., Bellaloui, N. and Molin, W. T. (2014) Corn yield response to reduced water use at different growth stages. Agric. Sci. 5, 1305.

Khalili, M., Naghavi, M. R., Aboughadareh, A. P. and Rad, H. N. (2013) Effects of drought stress on yield and yield components in maize cultivars (Zea mays L.).Int. J. Agron. Plant Prod. 4, 809-812.

Khoshvaghti, H., Eskandari-Kordlar, M. and Lotfi, R. (2013) Responses of morphological characteristic and grain yield of maize cultivars to water stress at reproductive stage. J. Biodivers. Environ. Sci. 3, 20-24.

Kramer, P. J. and Boyer, J. S. (1995) "Water Relations of Plants and Soils", Academic Press. San Diego. 495 p.

Kullberg, E. G. (2015) "Evaluation of Stress Coefficient Methods to Estimate Crop Evapotranspiration", Colorado State University,USA.

Kuşçu, H. and Demir, A. O. (2012) Responses of maize to full and limited irrigation at different plant growth stages. Uludağ Üniversitesi Ziraat Fakültesi Dergisi, 26.

Li, S., Kang, S., Li, F. and Zhang, L. (2008) Evapotranspiration and crop coefficient of spring maize with plastic mulch using eddy covariance in northwest China.Agricultural Water Management, 95, 1214-1222.

Mansouri-Far, C., Sanavy, S.A.M.M. and Saberali, S. F. (2010) Maize yield response to deficit irrigation during low-sensitive growth stages and nitrogen rate under semi-arid climatic conditions. Agric. Water Manage. 97, 12-22.

Egypt. J. Agron . 38, No. 3 (2016) 
Moosavi, S. G. (2012) The effect of water deficit stress and nitrogen fertilizer levels on morphology traits, yield and leaf area index in maize. Pak. J. Bot. 44, 1351-1355.

Mostafavi, K., Shoahosseini, M. and Geive, H. (2011) Multivariate analysis of variation among traits of corn hybrids traits under drought stress. Int. J. Agri. Science, 1, 416-422.

MWRIE (2014) "Water Scarcity in Egypt: The Urgent Need for Regional Cooperation among the Nile Basin Countries". Ministry of Water Resources and Irrigation of Egypt.

Pandey, R., Maranville, J. and Admou, A. (2000) Deficit irrigation and nitrogen effects on maize in a Sahelian environment: I. Grain yield and yield components. Agric. Water Manage. 46, 1-13.

Ritchie, S., Hanway, J. and Benson, G. (1993) How a corn plant develops. Special Report No: 48, Iowa State University.

Song-Feng, B., Dai Jun, Y., Zhang Lie, H. and Qing, Y. (1998) Effect of water stress on maize pollen vigor and filament fertility. Acta Agron. Simca, 24, 368-373.

Udomprasert, N., Kijjanon, J., Chusri-iam, K. and Machuay, A. (2005) Effects of water deficit at tasseling on photosynthesis, development and yield of corn. Kasetsart J. Nat. Sci. 39, 546-551.

Watson, D. J. (1952) The physiological basis of variation in yield. Adv. Agron. 4, 101-145.

Williams, L. and Ayars, J. (2005) Grapevine water use and the crop coefficient are linear functions of the shaded area measured beneath the canopy. Agric. For. Meteorol. 132, 201-211.

Yenesew, M. and Tilahun, K. (2009) Yield and water use efficiency of deficit-irrigated maize in a semi-arid region of Ethiopia. African Journal of Food, Agriculture, Nutrition and Development, 9(8), 1635-1651.

Yılmaz, E., Akçay, S., Gürbüz, T., Dagdelen, N. and Sezgin, F. (2010) Effect of different water stress on the yield and yield components of second crop corn in semiarid climate. Journal of Food, Agriculture \& Environment, 8, 415-421.

Zaki, Nabila M., Ahmed, Amal G., Hassanein, M.S., Manal, F.M. and Tawfik, M.M. (2014) Yield and yield components of two maize hybrids as influenced by water deficit and amino cat fertilizer. Middle East Journal of Applied Sciences, 4, 648-654.

Zarabi, M., Alahdadi, I., Akbari, G. A. and Akbari, G. A. (2011) A study on the effects of different biofertilizer combinations on yield, its components and growth indices of corn (Zea mays L.) under drought stress condition. Afr. J. Agric. Res. 6, 681-685.

(Received 21/10/2016; accepted 7/12/2016) 


\section{تأثير مستويات الري عند مراحل النمو المختلة على النمو والمحصول فى الأرة الثشامية

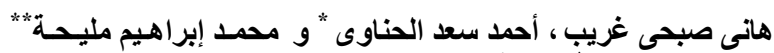

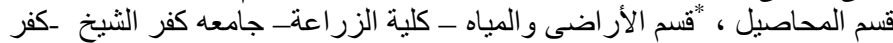

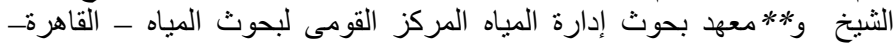

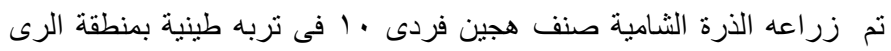

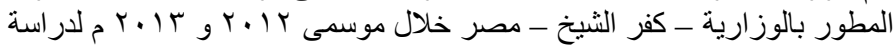

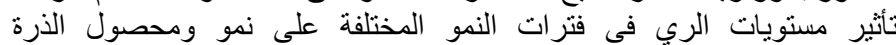

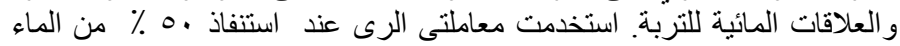

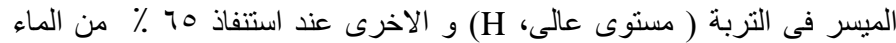

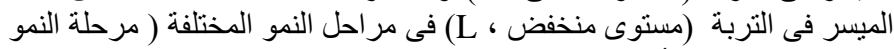

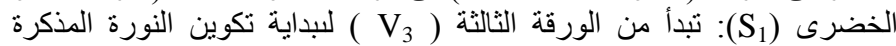

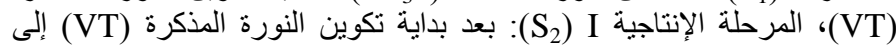

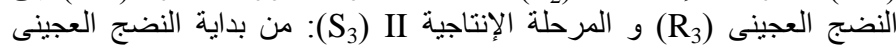
(R3)

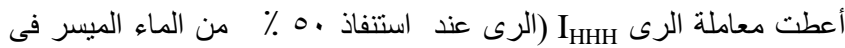

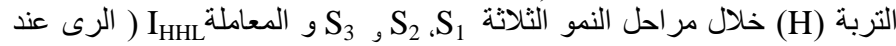

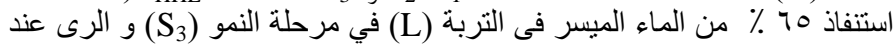

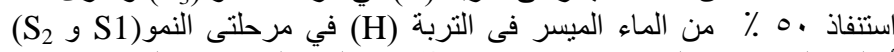

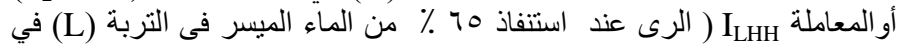

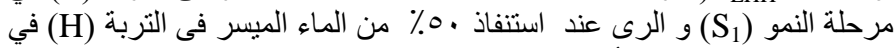

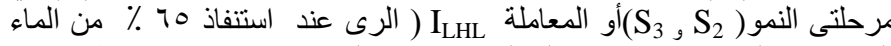

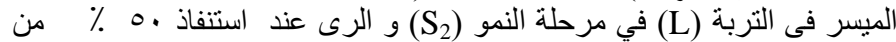

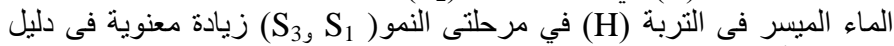

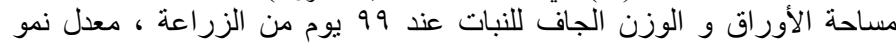

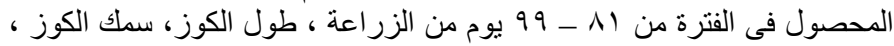

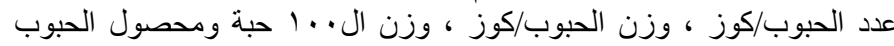

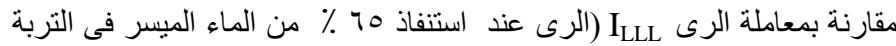

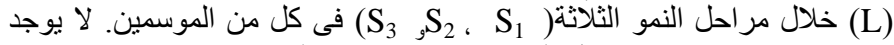

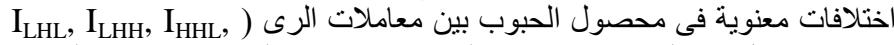

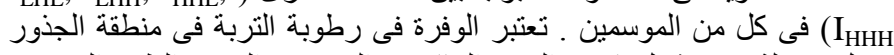

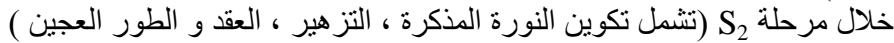

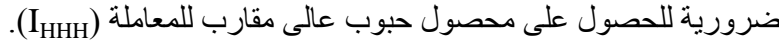

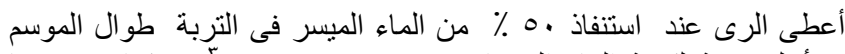
أعلى قيمة لكمية الماء المضاف (I (IHH)

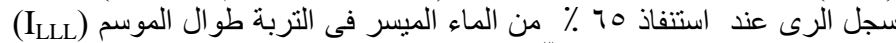

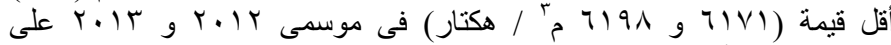

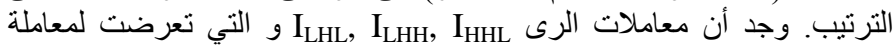

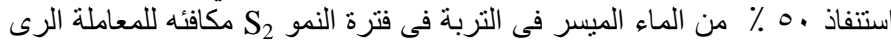

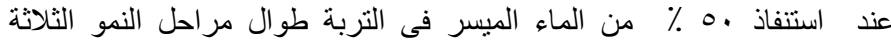

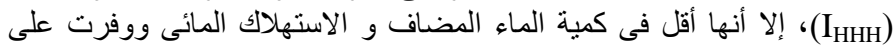




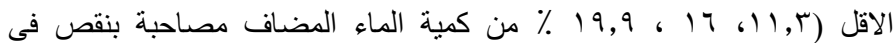

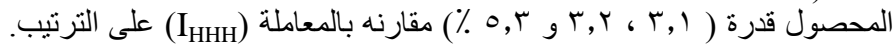

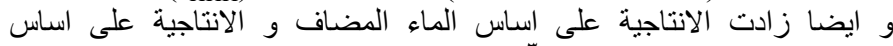

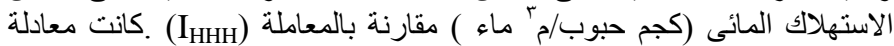

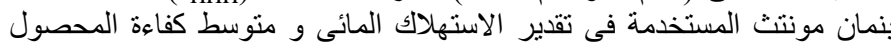

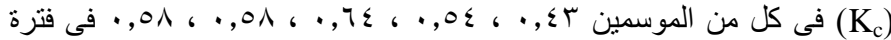

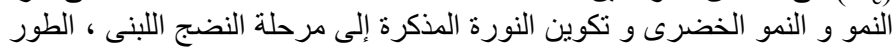

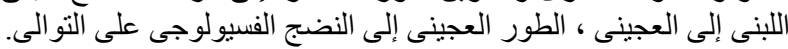

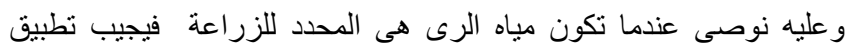

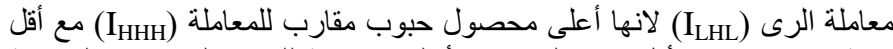

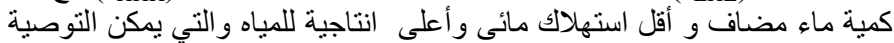

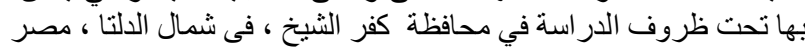

